\title{
寒冷地にある不飽和火山灰質土斜面の降雨模型 実験による崩壊現象とその評価
}

\author{
川村 志麻 1 三浦 清一2 ・石川 達也 3 ・横浜 勝司 4

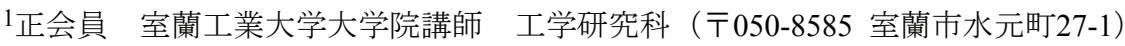 \\ E-mail: skawamur@mmm.muroran-it.ac.jp \\ 2フェロー会員 北海道大学大学院教授 工学研究院（干060-8628 札幌市北区北13条西8丁目) \\ E-mail: s-miura@eng.hokudai.ac.jp \\ 3 正会員 北海道大学大学院准教授 工学研究院 ( $\bar{T} 060-8628$ 札幌市北区北13条西8丁目) \\ E-mail: t-ishika@eng.hokudai.ac.jp \\ 4正会員 北海道大学大学院助教 工学研究院 ( \\ E-mail: yokohm@eng.hokudai.ac.jp
}

\begin{abstract}
寒冷地にある火山灰質土斜面の降雨時力学挙動を把握するために，一連の降雨模型実験が行われた。 は じめに降雨時の斜面表層崩壊に及ぼす諸要因の影響を定量化し, 力学的視点から崩壊の誘因を議論してい る. 次いで, 春季, 夏季に起こる表層崩壊を対象とした実験により, 凍結融解履歴が降雨時の力学挙動に 及ぼす影響を調べた。一連の実験結果は，表層崩壊は初期含水比に依存するものの，斜面内が保持できる 水量によって評価可能であることを示している，さらに，凍結融解履歴を有する斜面では，凍結部と非凍 結部の境界において構造変化が生じることによって崩壊が誘発される可能性のあることが斜面内のせん断 に伴う体積変化（ダイレイタンシー特性）に基づいて明らかにされている.
\end{abstract}

Key Words : slope failure, volcanic coarse-grained soil, rainfall, freeze-thaw action, model test

\section{1. まえがき}

北海道は，積雪寒冷地特有の融雪期における多量 の融雪水や凍結融解作用に起因寸る構成地盤の力学 的劣化の影響などによって, 斜面災害が生じや寸い 自然環境にあると言われている ${ }^{1)}$ 。また，比較的歴 史の新しい未風化火山灰土（火山性粗粒土）地帯が, 北海道の約 40\%を覆っており ${ }^{2)}$ ，そのことがさらに 斜面災害多発の誘因となっていると指摘されている。 例えば, 1999 年 4 月に起こった道央自動車道黒松 内地区の大規模な切土のり面崩壊 ${ }^{3)} 2003$ 年台風 10 号による日高地方の斜面崩壊・表層すべり ${ }^{4)}$ では, これらの影響が崩壊の一因であるとの報告がある。

現在，北海道にある多くの斜面の表層崩壊は，春 季では凍結層が不透水層として作用することによっ て誘発されること，また夏季では凍結層が融解する ことに起因寸る斜面構造の劣化によって誘発される ことが報告されており ${ }^{5)}$ (図-1参照)，それゆえ， 凍結融解作用が斜面の力学挙動に及ぼす影響を定量 的に評価した総合的な検討が必要である.

これまでに, 多くの研究者が降雨による斜面の崩
壊機構を明らかにしている。降雨による斜面崩壊に 関する既往の研究では, 飽和状態での有効応力減少 に起因する崩壊機構(例えば6) の考察に加えて, 不飽和 力学挙動に基づいた崩壊機構(例えば7),8),99,10) が議論され てきている，また，種々のモニタリング技術の利用 により崩壊予知法 ${ }^{11), 12)}$ の確立が進んでいる.さらに 地震と降雨の複合災害として斜面崩壊機構を論じた

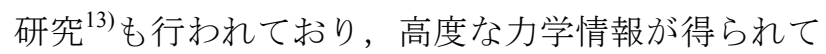
いる.

一方, 凍結融解履歴を受けた斜面の崩壊機構を議 論した研究, 例えば Harris \& Davies ${ }^{14)}$ は凍結（凍 上）と融解時に起こる斜面内変形挙動を明らかにし， このことが崩壊に及ぼすことを定量的に評価してい るものの, 凍結融解履歴が降雨時の斜面崩壊機構に 及ぼす影響を詳細に調べた研究は未だ立ち遅れてい ると言える。

そこで本研究では, 北海道に広く分布している火 山灰質土が基岩上に堆積した斜面およびその土質材 料によって構成された切土・盛土形状の斜面構造を 想定 ${ }^{4)}$ し, まず降雨時の斜面崩壊に及ぼす諸要因の 影響を調べ, より詳細な力学的視点から表層崩壊の 


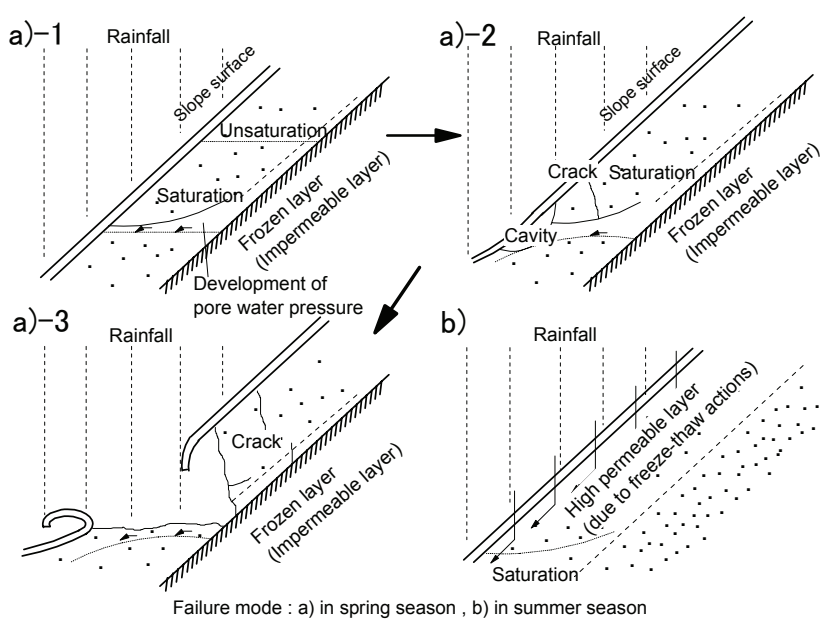

図-1 積雪寒冷地にある切土斜面の崩壊モード ${ }^{5)}$; (a)春季型災害, (b)夏季型㷋害

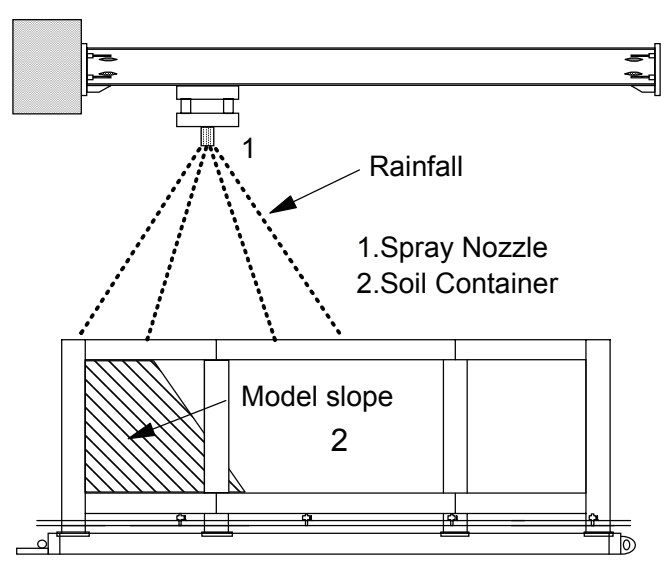

図-2 本試験で用いた模型実験装置

誘因を議論している，次いで，春季，夏季に起こる 斜面崩壊現象を解明するために，一連の凍結融解履 歴を与えた降雨模型実験を実施し, 履歴の有無が降 雨時の斜面力学挙動に及ぼす影響を調べている．得 られた結果より, 降雨による斜面崩壊と斜面内の保 水特性の変化ならびに体積変化（ダイレイタンシー 特性）にもとづいて崩壊機構が説明されている.

\section{2. 模型実験の方法と斜面崩壊の定義}

\section{（1）試験装置と模型実験の方法}

本研究で用いた試験装置の全体図を図-2 に示す。 模型土槽の内寸法は幅 $2000 \mathrm{~mm}$, 高さ $700 \mathrm{~mm}$, 奥行 き $600 \mathrm{~mm}$ である. 前面には厚さ $20 \mathrm{~mm}$ の強化ガラ スが設置され，人工降雨付与に伴う斜面の変形挙動 が観察できるようになっている，なお，本研究では グリース塗布などによる土槽側面の摩擦除去は行っ ていない.

本研究で使用した試料は火山性粗粒土に分類され
る支第カルデラを噴出源（支䇗第一テフラ（Spfa-1）） とする柏原火山灰土 $\left(\rho_{s}=2.34 \mathrm{~g} / \mathrm{cm}^{3}, \quad \rho_{d \max }=\right.$ $0.553 \mathrm{~g} / \mathrm{cm}^{3}, \quad \rho_{d \min }=0.352 \mathrm{~g} / \mathrm{cm}^{3}, \quad \rho_{\text {din-situ }}=0.530 \mathrm{~g} / \mathrm{cm}^{3}$, $\left.D_{50}=1.25 \mathrm{~mm}, U_{c}=3.1, F_{c}=1.3 \%\right)$ である。なお，本 火山灰土の物理・学特性は既往の研究 ${ }^{15)}$ に詳しい. 本研究では, 所定の含水比に調整した試料を, $\rho_{d}=$ $0.45 \mathrm{~g} / \mathrm{cm}^{3}$ (緩詰め) と $\rho_{d}=0.48 \mathrm{~g} / \mathrm{cm}^{3}$ (密詰め) にな るように模型斜面を作製している。なお，密度のバ ラツキは，それぞれの目標密度の $5 \%$ 以内である.

以下に作製手順を示寸。

1)緩詰めの場合 : 所定の模型斜面になるようにアル ミサッシを設置し, 試料を空中より落下させて堆 積させる。

2)密詰めの場合：1）と同様に試料を堆積させた後, 粒子破砕が起こらないように，ローラーで 1 層当 たり（厚さ $10 \mathrm{~cm} ） 1$ 回の締固めを行う.

3)所定の高さまで試料を堆積させ，その後，アルミ サッシの上に鋭利な刃先を有する鉄板を滑らせな がら，余分な試料を取り除く.

凍結融解履歴を与えた場合では，上記と同様の方 法で斜面を作製した後，その表面を斜面と同形状の 鉄板で覆い，その上にドライアイスを設置し，8 時 間強制的に凍結させている。一例として，写真-1 と図-3 は, 凍結後の斜面の状況と凍結中の斜面内 の温度変化を, 後述する位置に設置した熱電対セン サー（T1〜 T9）によって計測したものである. 図 示のように, 温度分布では深さ $50 \mathrm{~mm}$ までマイナ ス温度になっているが，目視ではおよそ $80 \mathrm{~mm}$ ま で凍結が確認されている。 また, 融解は基本的に室 温 $20^{\circ} \mathrm{C}$ で与えている. 具体的な凍結融解過程の温 度変化とその分布を図-4 と図-5 に示す。なお，融 解過程における斜面内からの水分供給（移動）は初 期含水比の状態下における保水分によって与えてお り, 地下水面を設定するといった操作は, 本研究で は行っていない，本試験で称する融解履歴とはこの ような履歴を指寸。

本研究では, 斜面崩壊機構を把握するためのパラ メータとして, 間隙水圧, 飽和度, Particle Image Velocimetry (PIV) 解析 ${ }^{16)}$ によって算出される斜 面内のせん断ひずみを用いている. 間隙水圧および 飽和度は, 間隙水圧計 (pw1 p pw6) と土壌水分計 （sm1〜 sm6）によって計測されている. なお，本 試験で用いた間隙水圧計には, 受圧部にセラミック フィルター等の高感度フィルターを用いていない。 そのため, 計器設置直前まで受圧部のフィルター部 分の飽和化を図るなど，計測改善に努めたが，負圧 の具体值に関しては参考值と見なされる. 一方，得 られた間隙水圧挙動では, 後述のように, ほとんど 


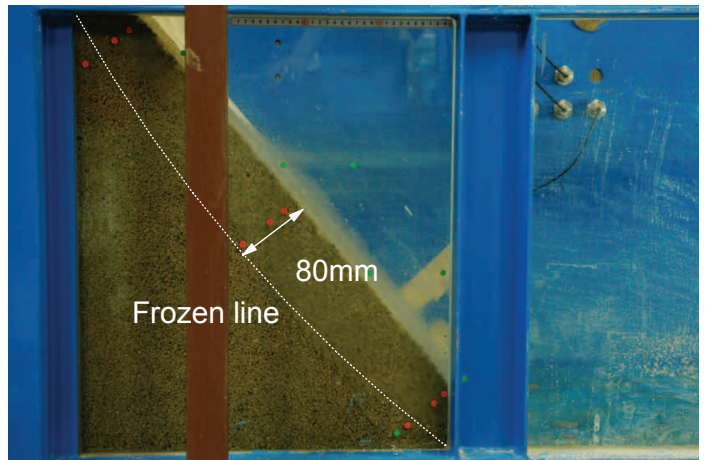

写真-1 凍結後の斜面の状況

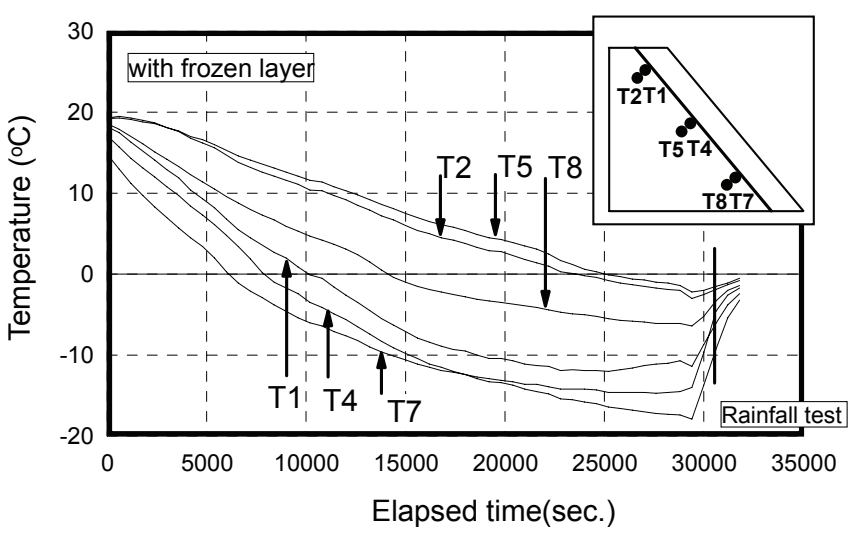

図-3 凍結時の斜面内の温度変化

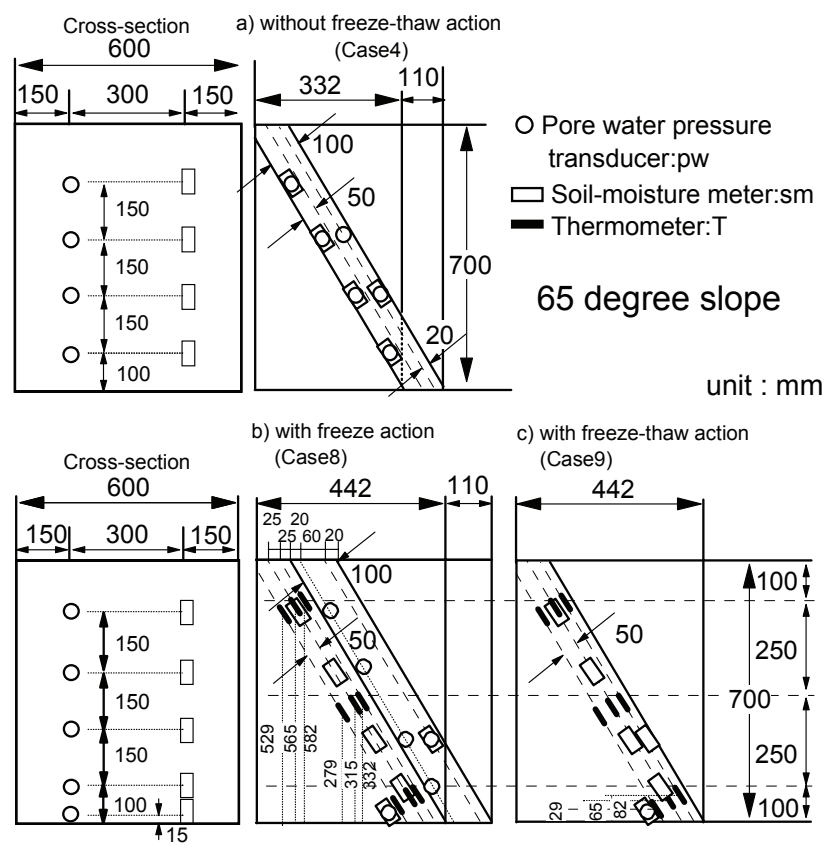

図-6 代表的な斜面形状と計器配置図

のケースにおいてサクションに伴う負の間隙水圧は 生じなかった。このことは，先の間隙水圧計受圧部 の感度にも影響を受けるが，本研究では本斜面の間 隙構造が大きいことに起因していると考えられ，サ クションの崩壊に対する寄与はかなり低いと考えら

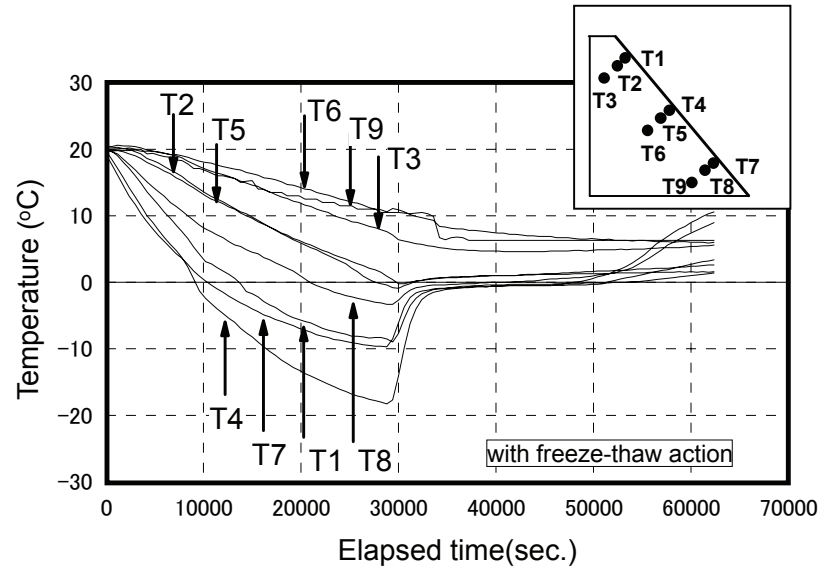

図-4 凍結融解時の斜面内の温度変化

(a) During freeze action

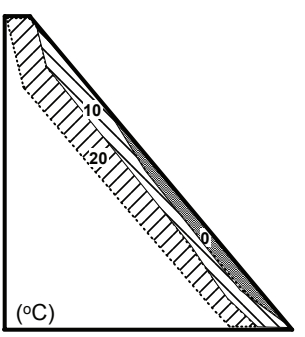

10,800sec.(180min.)

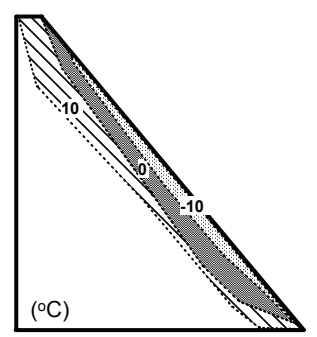

28,800 sec.(480min.) (b) During thaw action

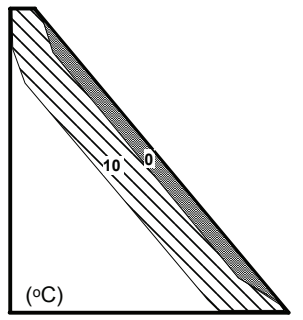

43,200sec.(720min.)

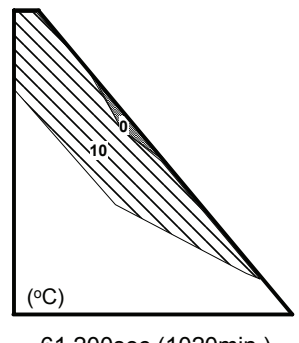

61,200sec.(1020min.)
図-5 凍結融解時の温度分布

れる.このことはサクションの低下によるせん断強 度の低下を調べた要素試験結果からも明らかにされ ている ${ }^{17)}$ 。これらの事実から，本試験の対象とな るところは浸透現象にともなう間隙水圧（正圧）変 動になる。一方, 土壤水分計は斜面の密度を種々変 化させた状態でキャリブレーションを行い，初期模 型斜面密度に対応できるようにしているが，す心゙り に伴う体積変化の影響に関しては現象把握の困難さ から考慮していない，以下の議論では，飽和度の具 体值ではなく，その傾向の把握を第一の目的にした。 模型斜面の代表的な形状と計測機器の設置位置を図 -6 に示す.

実施した降雨実験は，(1)不透水層が斜面内に存 在するケース，(2)斜面内に凍結層が存在するケー ス，(3)斜面の初期含水比を変化させたケースと(4) 凍結融解履歴を与えたケースである（表-1 参照）.

(1)不透水層が存在するケース（Case1～Case5） 
表-1＼cjkstart試験条件と試験ケース

\begin{tabular}{|c|c|c|c|c|c|c|c|c|c|c|}
\hline & Case1 & Case2 & Case3 & Case4 & Case5 & Case6 & Case7 & Case8 & Case9 & Case10 \\
\hline Slope condition & \multicolumn{5}{|c|}{ Without freeze-thaw action } & \multicolumn{3}{|c|}{ With freeze action } & With freeze-thaw action & Without freeze-thaw action \\
\hline Freeze-thaw action cycles & & & & & & & 1 & & 1,2 & \\
\hline Slope angle $\alpha\left(^{\circ}\right)$ & 45 & 50 & 55 & 65 & 50 & 50 & 55 & & 65 & 65 \\
\hline Initial moisture content $w_{0}(\%)$ & \multicolumn{8}{|c|}{70} & $20,40,55,60,70$ & $20,40,55,60,70$ \\
\hline Length of base $B(\mathrm{~mm})$ & 696 & 636 & 572 & 442 & $\begin{array}{c}603,636,669 \\
702,767\end{array}$ & 767 & 702 & 552 & 442 & 442 \\
\hline Rainfall intensity $R(\mathrm{~mm} / \mathrm{h})$ & \multicolumn{3}{|c|}{100,60} & 100 & 100 & \multicolumn{5}{|c|}{100} \\
\hline Thickness of layer $\mathrm{t}(\mathrm{mm})$ & \multicolumn{4}{|c|}{100} & $\begin{array}{c}75,100,125,150 \\
200\end{array}$ & 100 & 50 & 100 & & \\
\hline Density $\rho d\left(\mathrm{~g} / \mathrm{cm}^{3}\right)$ & \multirow{2}{*}{\multicolumn{3}{|c|}{$\begin{array}{l}0.45,0.48 \\
0.33,2.81\end{array}$}} & $0.45,0.48$ & 0.45 & \multicolumn{5}{|c|}{$0.45,0.48$} \\
\hline Friction $\mu$ & & & & 4.31 & 0.33 & \multirow{2}{*}{\multicolumn{3}{|c|}{4.31}} & & \\
\hline Thaw time(hr.) & & & & & & & & & $9,12,40$ & \\
\hline
\end{tabular}
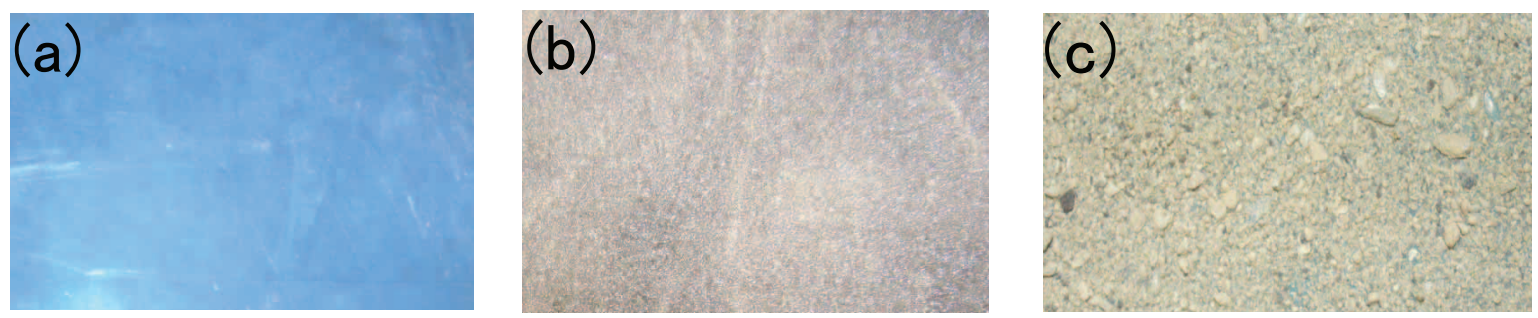

写真-2 不透水層表面の状況 ; (a) $\mu=0.33$, (b) $\mu=2.81$, (c) $\mu=4.31$

では，不透水層がある層厚の下で斜面表面と平行し て存在していると仮定し, 強度が十分にある不透水 性の材料を用いることによって，簡易的に再現した。 試験では斜面角 $\alpha\left(=45,50,55,65^{\circ}\right)$ ，降雨強 度 $R(=100,60 \mathrm{~mm} / \mathrm{h})$ ，斜面密度 $\rho_{d}(=0.45,0.48$ $\left.\mathrm{g} / \mathrm{cm}^{3}\right)$, 不透水層境界部の摩擦係数 $\mu^{18)}(=0.33$, $2.81,4.31)$, 斜面層厚 $t(=75,100,125,150$, 200mm）の違いによる力学挙動の変化を調べてい る. 本試験で称する摩擦係数は, 目標と寸る摩擦度 を有する床となめらかな鉛直壁に, 質量が均一な棒 を立て掛け，その棒がすべり出す時の床と棒との角 度 $\theta$ から静止摩擦係数 $\mu$ を簡易的に算出したもので ある，そのため，摩擦面の凹凸の影響が含まれてお り, 真の摩擦係数を測定したものではないが, 摩擦 特性の影響を調べるための1つの手段として, ここ ではこの指標を採用している. 3 種類の不透水層表 面の状況を写真-2 に示寸. (a) はプラスチック板を, （b）はサンドペーパー（120 番）を，(c) は模型斜面 試料を貼付けたものになる。 また, 本研究では斜面 角 $\alpha$ が $45^{\circ}$ 以上の高傾斜の斜面について検討して いるが，これは模型実験において崩壊が起るものを 対象にしたためである. 寸なわち極值 $\left(45^{\circ}\right.$ と $\left.65^{\circ}\right)$ 間の崩壊時力学挙動が議論されている.

(2)斜面内に凍結層が存在するケース（Case6〜 Case8）では, 3 種類の斜面角 $\alpha\left(=50,55,65^{\circ}\right)$ について(1)と同様の実験を実施し, 凍結層が不透 水層として働くのか否かを検討している.

次いで，(3)斜面の初期含水比 $w_{0}(=20,40,55$, 60，70\%）を変化させたケースでは, 初期含水比の 違いが崩壊機構に及ぼす影響を調べている

（Case10）。なお, 初期含水比の違いが崩壊挙動に
及ぼす影響を極力小さくするために，すべての模型 実験は斜面作製後 30 分から開始し, 併せて初期の 飽和度のバラツキは約 5\%以内のものを採用した ${ }^{19)}$. その結果にもとづいた(4)凍結融解履歴を与えた ケース（Case9）では, 融解速度の違い（融解時 間：9，12，40 時間）による力学挙動の変化を調べ ている.

なお，表中の各試験ケース間において同じ条件の ものが存在するが, これは 1 つの試験結果を意味し ている.

試験手順を以下に示す.

1)G.L.+2.4 m に設置したスプレーノズルの種類, 位 置, 水圧を変化させて, 所定の降雨強度 $R \quad(=100$, $60 \mathrm{~mm} / \mathrm{h}$ ) になるように調節する.

2)模型斜面作製後, 図-2 に示寸スプレーノズルか ら水を噴霧すると同時に, 土壤水分量, 間隙水圧 の測定を開始する. 凍結融解履歴を与えるケース では, 凍結開始と同時に, 土壤水分量および熱電 対センサーにより斜面内の温度の測定を開始する. 融解後, 降雨試験を行う際にはスプレーノズルか ら水を噴霧すると同時に, 間隙水圧の測定を開始 する。

3)降雨を開始してから斜面形状に明瞭な変形（崩 壊）が現れるまで，または 1 時間の降雨履歴を与 えるまで，実験を続けている，なお，降雨によっ て浸透した水は, 底部に設置したポンプから強制 的に排水されている. また, 斜面以外に降った雨 については，全土槽エリアをシートで覆い，雨樋 を通じて集水されている. 本研究では, この降雨 量（スプレーノズルから噴霧したすべての水量） とポンプから排水した水量及び雨樋より集水した 

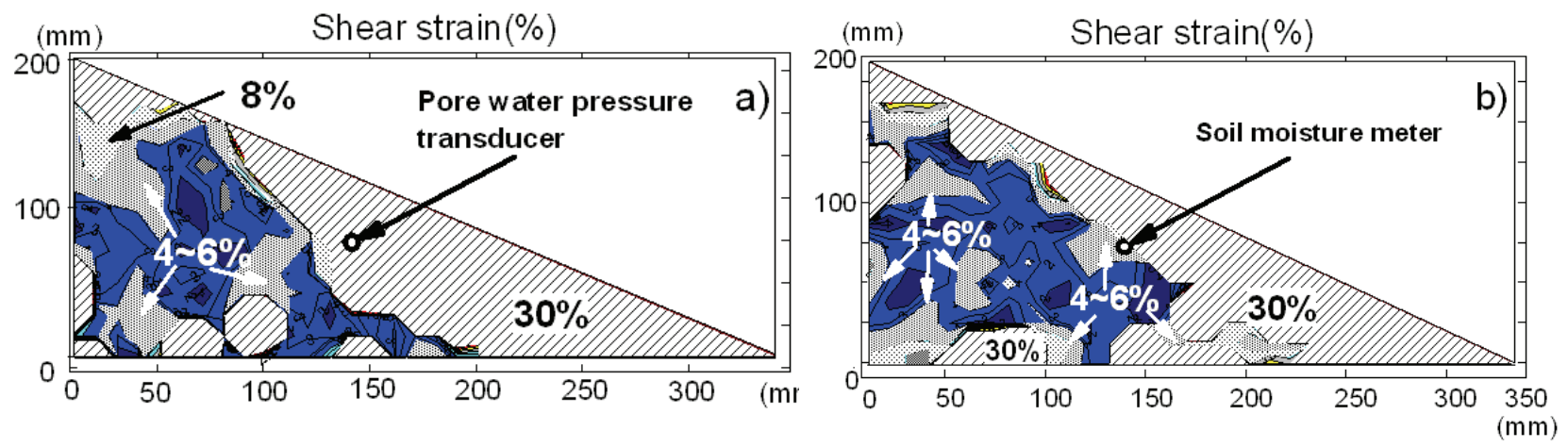

図-7 PIV 解析による飽和度ピーク時のせん断ひずみ分布 ${ }^{20)}$

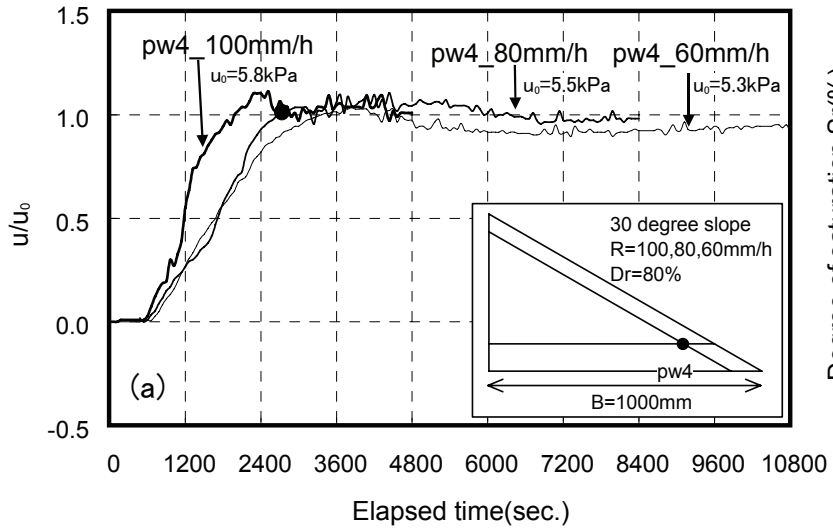

図-8 斜面崩壊時の力学特性 ${ }^{20)}$;

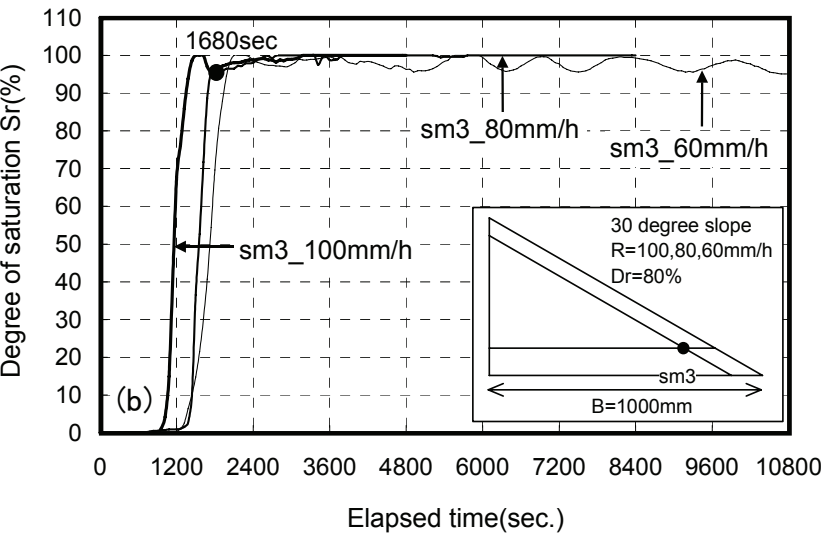

（a)間隙水圧の変化， (b)飽和度の変化
水量の差を斜面内保水量 $V_{w}$ と定義している.

\section{（2）斜面崩壊の定義}

過去の研究 ${ }^{20)}$ では, すべり線上に位置する土壤水 分計の飽和度がピークに達した 5〜10 秒後に斜面崩 壊が生じている. 図-7に, 乾燥状態で作製した豊 浦砂斜面（斜面角 $\alpha=30^{\circ}$, 雨量強度 $R=80 \mathrm{~mm} / \mathrm{h}$ ) の飽和度ピーク時点の PIV 解析より得たせん断ひず 夕分布とその設置部分（図中○印）の一例を示寸.

図より，飽和度ピーク時では斜面表層部のせん断ひ ずみは 30\%に達し，計器設置付近のそれは 4 6\%発 生していることがわかる。このことは柏原火山灰土 斜面においても同様に確認されており ${ }^{20)}$, 試料や後 述する斜面角, 降雨強度, 密度, 摩擦係数の違いに かかわらず，すべて満足されていたことから，この 時点を塑性平衡状態と判断している。一方, 土壤水 分計と同位置に設置した間隙水圧挙動では，斜面変 状が見られた時点（図中の印）の間隙水圧值 $u_{0}$ によ り正規化した間隙水圧の変化は, 飽和度の変化と比 べて敏感ではないことがわかる（図-8 参照）。

よって, 本研究では飽和度ピーク時に斜面内のせ ん断ひずみが 4 〜\%になった時点を斜面崩壊と定義 し, 以降の議論に用いている.

\section{3. 試験結果と考察}

\section{（1）降雨時の斜面表層崩壊に及ぼす諸要因の影響}

はじめに, 不透水層が斜面内に存在するケース （Case1〜Case5）における斜面崩壊に及ぼす降雨強 度, 斜面角, 斜面密度, 不透水層境界部の摩擦およ び斜面層厚の影響を述べる.

写真-3 と図-9 は不透水層を有寸る斜面の代表的 な崩壊の様子と崩壊時の PIV 解析結果をせん断ひ ずみ分布として示したものである。斜面角 $\alpha=50^{\circ}$ ， 降雨強度 $R=100 \mathrm{~mm} / \mathrm{h}$, 不透水層境界部の摩擦係数 は $\mu=0.33$ である. 図および写真より, 降雨によっ てすべりに伴う斜面崩壊が起っていることが明らか である.ここで, 本研究では動画観察によってす心゙ り土塊がほぼ剛体的な動きをした境界をすべり線と している。一方, PIV 解析では斜面下部境界部にお いて 4〜20\%のせん断ひずみが生じているが，これ はす心゙りに伴う土粒子の移動が PIV 結果に敏感に 反映されたものであり，斜面底部の境界部がすべり 崩壊に対して影響を及ぼしたものではないことを併 せて確認している.

このときの斜面内の飽和度挙動について着目寸る と, 表層部に設置している $\mathrm{sm} 4$ では, 飽和度はピ 一ク（図中の印）を示した後，急激に減少している 


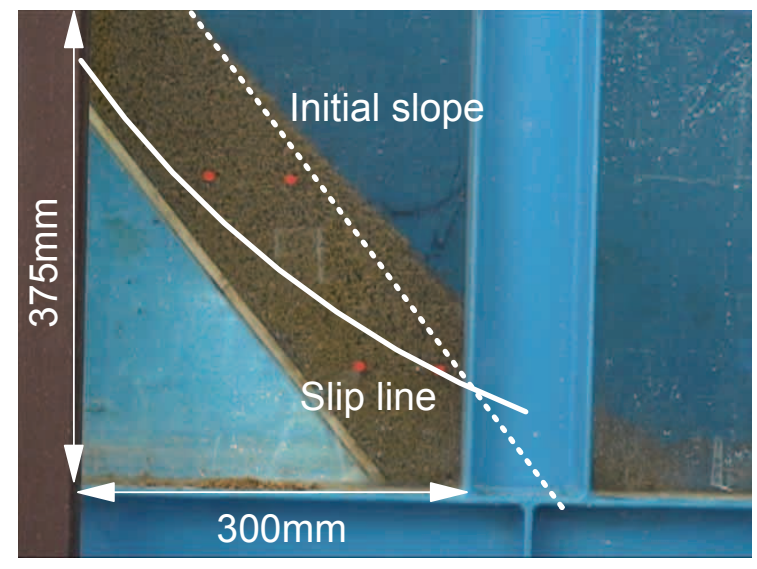

写真-3 不透水層を有する斜面の代表的な崩壊の様子

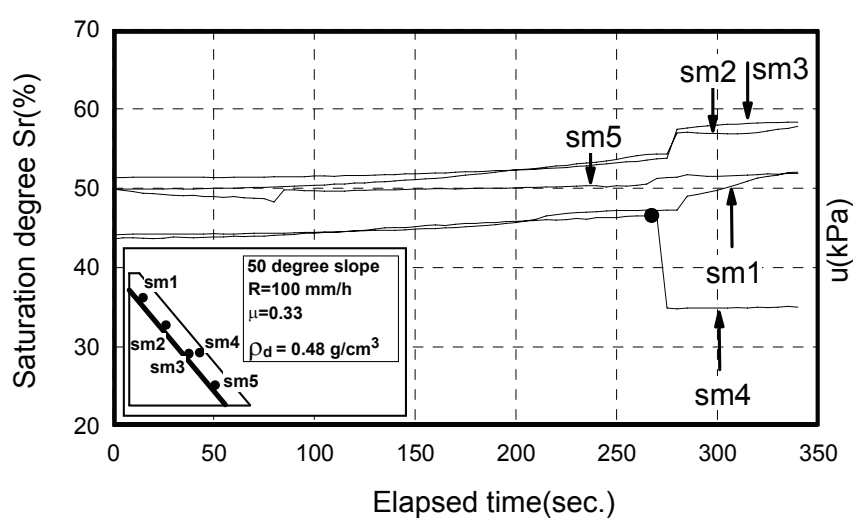

図-10 降雨実験における飽和度挙動

（図-10 参照）. 他の位置の飽和度挙動と比較する と, 表層部の飽和度 sm4 は, すべり線発生位置よ り深部に設置した飽和度（例えば， sm2 と sm3）よ りもやや大きく変化する傾向にある。これは，す心゙ り線付近では，すべり線の発達に伴うダイレイタン シーによって, 斜面の骨格構造に変化が現れたこと を示すものである。一方，間隙水圧は試験開始後， 増加傾向にあるものの, かなり小さく, すべりに伴 う明確な変化は認められない（図-11 参照）。なお, 本斜面は不飽和状態にあることから，本ケースのよ うに初期段階において部分的に負圧を示したケース も存在したが，ほとんどのケースにおいてそのよう な現象は確認されなかった。

以上のことから，適切な位置に設置された土壌水 分計等の計測器によって斜面内保水量の変化を追跡 することは，表層崩壊を評価する上で重要であると 言える.

図-12 は降雨強度の違いによる飽和度の变化を示 したものである。代表的に，斜面角 $\alpha=45^{\circ}$ ，降雨 強度 $R=100 \mathrm{~mm} / \mathrm{h}$ と $60 \mathrm{~mm} / \mathrm{h}$, 摩擦係数 $\mu=0.33$ のも のを示す. $R=60 \mathrm{~mm} / \mathrm{h}$ の場合では, 飽和度は降雨開

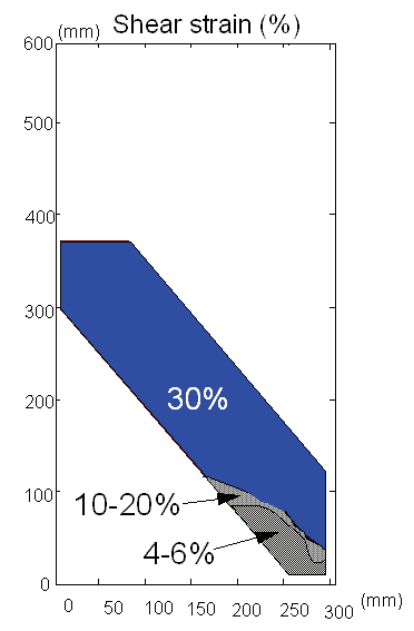

図-9＼cjkstart崩壊直後のせん断ひずみ分布

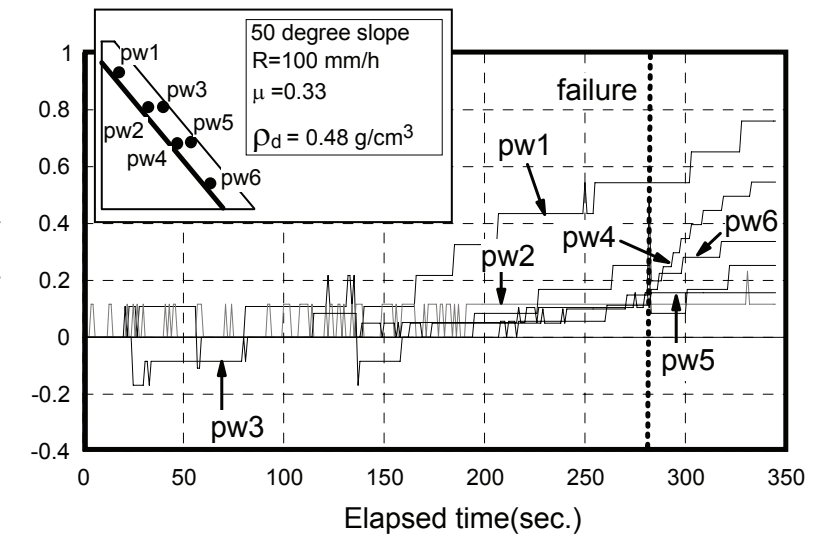

図-11 降雨実験における間隙水圧挙動

始後徐々に上昇し，表層部（sm4）と底部（sm5） において開始後 375 秒でピーク（図中○印）に達し， その後減少している。同様に，100mm/h の場合では， sm4 の飽和度は 245 秒でピーク（図中○印）に達し， その後減少している.

図-13 はすべり線の付近の間隙水圧挙動を示した ものである. 試験開始後, 増加傾向にあるものの, 先ほどと同様, その值はかなり小さく, すべりに伴 う明確な変化は認められない。

次に，飽和度ピーク時における斜面内のせん断ひ ずみを図-14 に示す。両ケースともにせん断ひずみ は計器周辺では 4〜 6\%, 表層部では 30\%に達して おり, その変形挙動に相違は認められない. 以上の ことから, 降雨強度の違いは変形挙動に影響を及ぼ さないものの，飽和度の発達，すなわち崩壊に至る までの時間に確実に影響を与えている ${ }^{21)}$.

斜面密度の違いによる飽和度の変化を図-15 に示 す（破線： $\rho_{d}=0.45 \mathrm{~g} / \mathrm{cm}^{3}$, 実線 : $\rho_{d}=0.48 \mathrm{~g} / \mathrm{cm}^{3}$ ). 試験条件は, 斜面角 $\alpha=50^{\circ}$, 降雨強度 $R=100 \mathrm{~mm} / \mathrm{h}$, 摩擦係数 $\mu=2.81$ であり, 各飽和度は初期值 $S r_{0}$ に より正規化している。図より, 崩壊（図中○印）に 


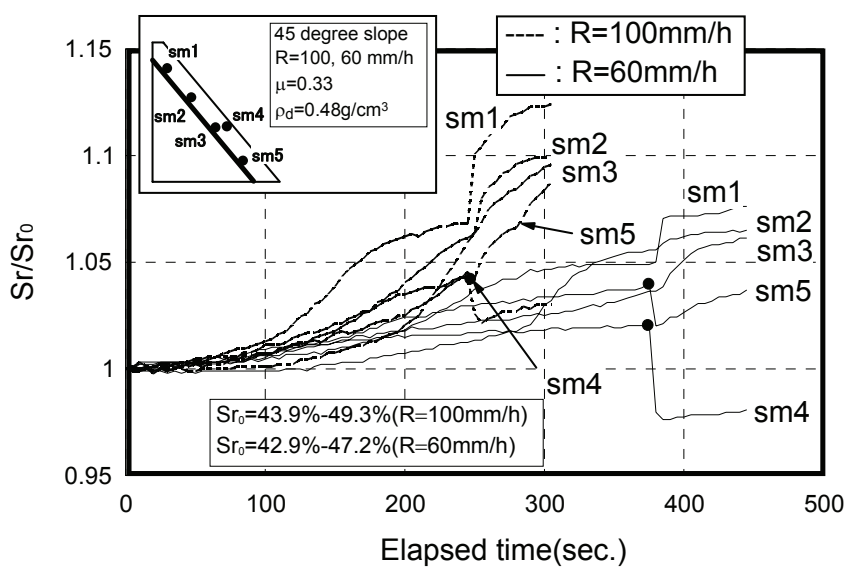

図-12 降雨強度の違いによる飽和度の変化

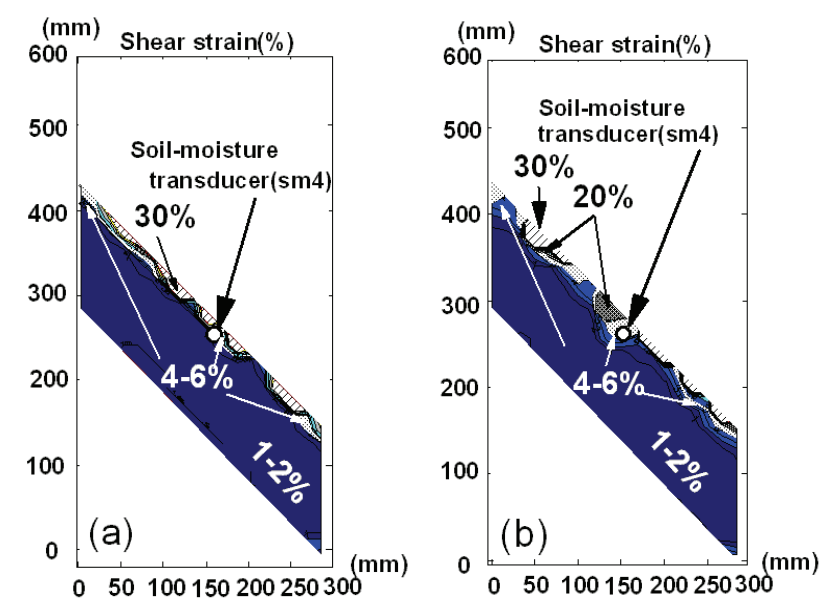

図-14 飽和度ピーク時のせん断ひずみ分布; (a) $R=100 \mathrm{~mm} / \mathrm{h}, \quad$ (b) $R=60 \mathrm{~mm} / \mathrm{h}$

至るまでの時間に差異が認められる。この崩壊時間 の差は, 密度増加によるせん断抵抗力の増加を意味 しているものであろう。また，ダイレイタンシー挙 動の差による崩壊後の飽和度減少率に差は確認され るものの, 飽和度発達過程では明確な相違はない。

このことは間隙水圧挙動においても同様である（図 -16 参照）。図示は省略するが，PIV 解析による斜 面内のせん断ひずみ分布においてもその相違は認め られなかった。 それゆえ, 本研究で用いた火山灰質 土斜面の範囲では, 崩壊機構に対する密度の影響は 小さいと考えられる.

次に， $45^{\circ}$ 斜面および $50^{\circ}$ 斜面の崩壊後の斜面 形状の比較を写真-4 に示寸. 降雨強度 $R=60 \mathrm{~mm} / \mathrm{h}$, 摩擦係数 $\mu=2.81$ である. 写真より, $50^{\circ}$ 斜面と $45^{\circ}$ 斜面で変形パターンに違いが認められる。すな わち, 角度が低い場合では明瞭なすべり線が現れな いようである。図-17 に示す飽和度挙動では, 変形 パターンの違いに起因する飽和度の若干の変化は認 められるものの, 斜面角の違いによる基本的な相違 はない.

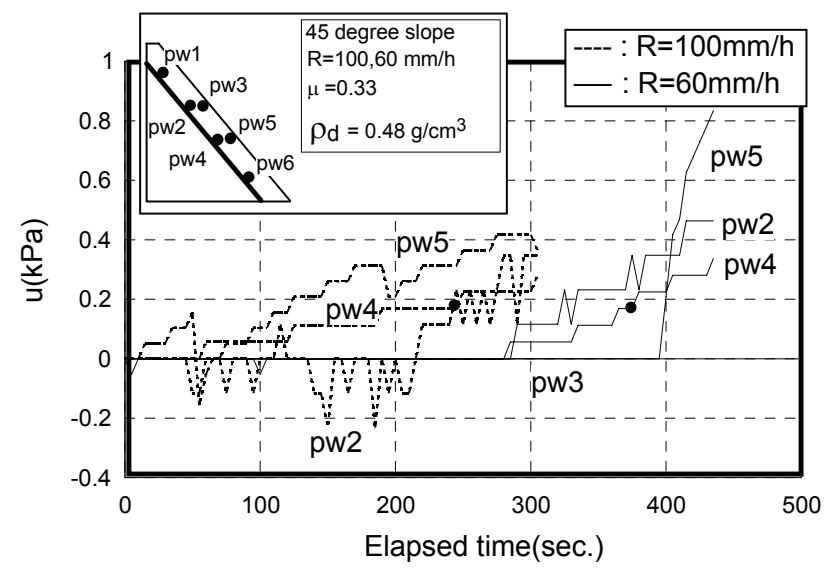

図-13 降雨強度の違いによる間隙水圧の変化

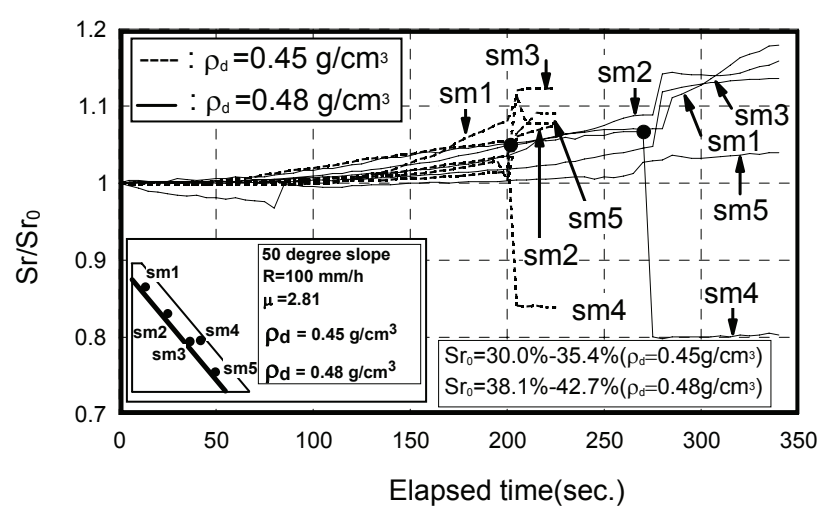

図-15＼cjkstart密度の違いによる飽和度の変化

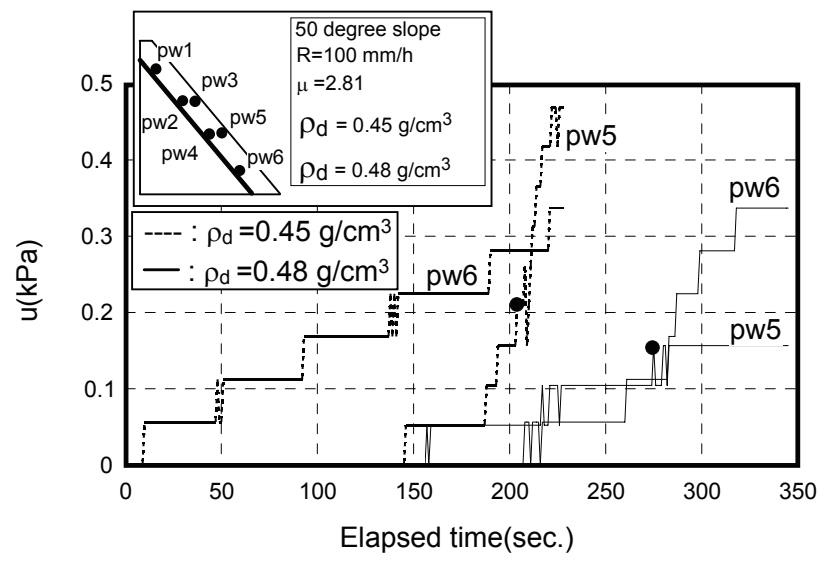

図-16 密度の違いによる間隙水圧の変化

図-18 は，不透水層境界部の摩擦の違いによる飽 和度の変化を示したものである（破線： $\mu=0.33$

（smooth），実線： $\mu=2.81$ （Rough））. 斜面角 $\alpha=50^{\circ}$ ，降雨強度 $R=60 \mathrm{~mm} / \mathrm{h}$, 斜面密度 $\rho_{d}=0.45$ $\mathrm{g} / \mathrm{cm}^{3}$ である。図より, すべり線発生位置付近の飽 和度 $(\mathrm{sm} 4)$ は, 前述と同様, 崩壊時を境に増加一 減少傾向を示す，そのピーク時における斜面内のせ 几断ひずみ分布を図-19 に示す。摩擦係数 $\mu=2.81$ の場合（（a）図参照）では，表層部では 4〜 $6 \%$ ，そ の他の部分は 1〜2\%のせん断ひずみが発生してい 

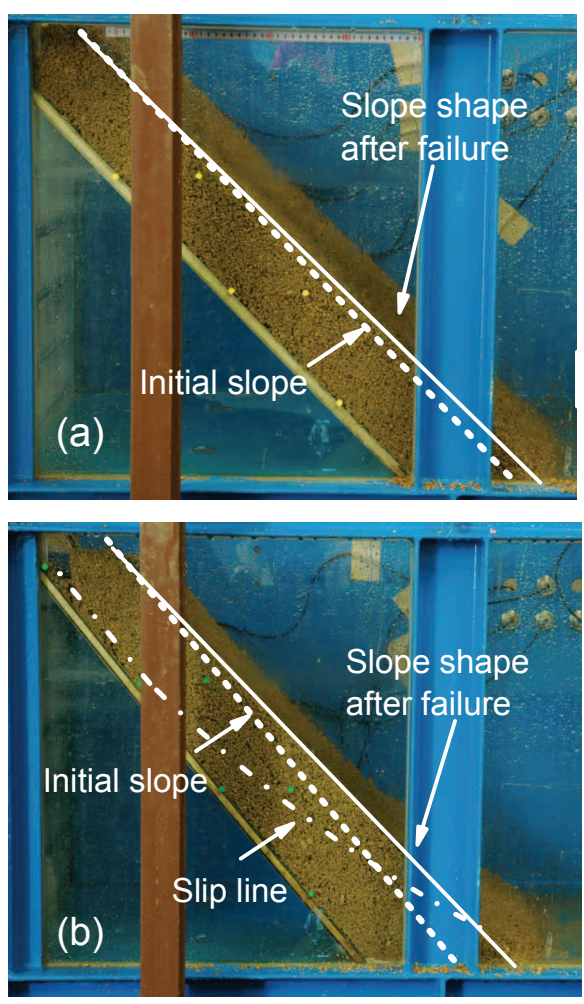

写真-4 崩壊後の斜面形状の様子 ; (a) $45^{\circ}$ 斜面, (b) $50^{\circ}$ 斜面

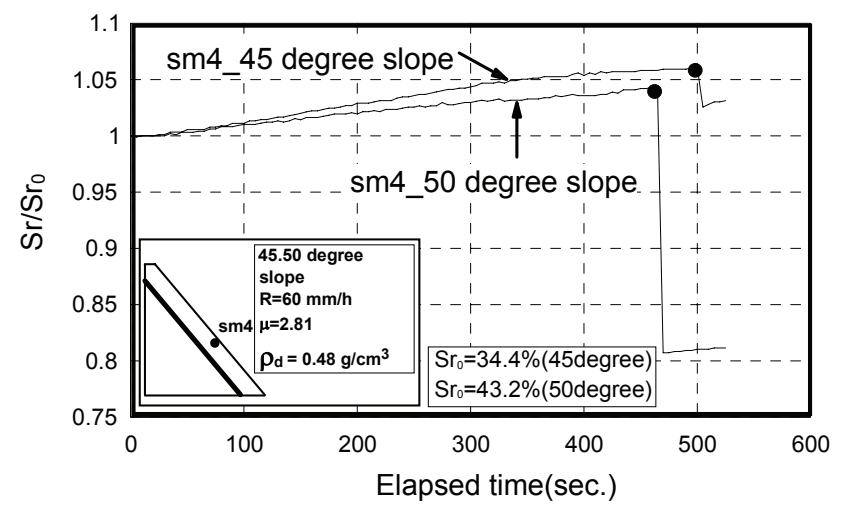

図-17 斜面角の違いによる飽和度の変化

る. 一方，摩擦係数 $\mu=0.33$ の場合（(b)図参照）で は，せん断ひずみは不透水層境界部付近で 4〜 6\% 程度発生しており，摩擦係数 $\mu=2.81$ の場合に比べ て大きい, 不透水層境界部の摩擦度の違いは，当然 のことながら，主に斜面の変形挙動，特にすべり線 の発達に影響を及ぼしている.

次に, すべり線発生位置に着目し，斜面層厚を変 化させた場合について述べる（Case5）。斜面角 $\alpha=50^{\circ}$ ，降雨強度 $R=100 \mathrm{~mm} / \mathrm{h}$, 斜面密度 $\rho_{d}=0.45$ $\mathrm{g} / \mathrm{cm}^{3}$ ，層境界部の摩擦係数 $\mu=0.33$ である. 層厚は $t=75 ， 100 ， 125 ， 150,200 \mathrm{~mm}$ の 5 ケースである.

写真-5 (a) と (b) はそれぞれ層厚 $t=75 \mathrm{~mm}$ と 100 $\mathrm{mm}$ のケースにおける崩壊後の斜面形状を示したも

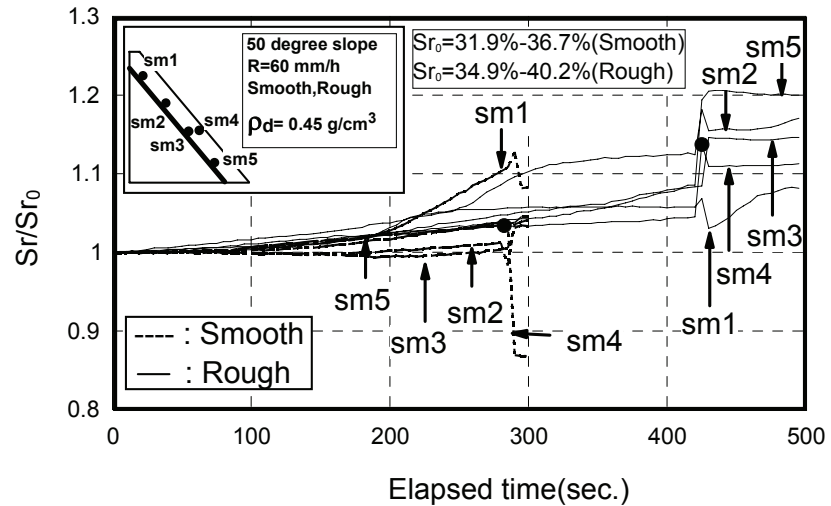

図-18 摩擦係数の違いによる飽和度の変化
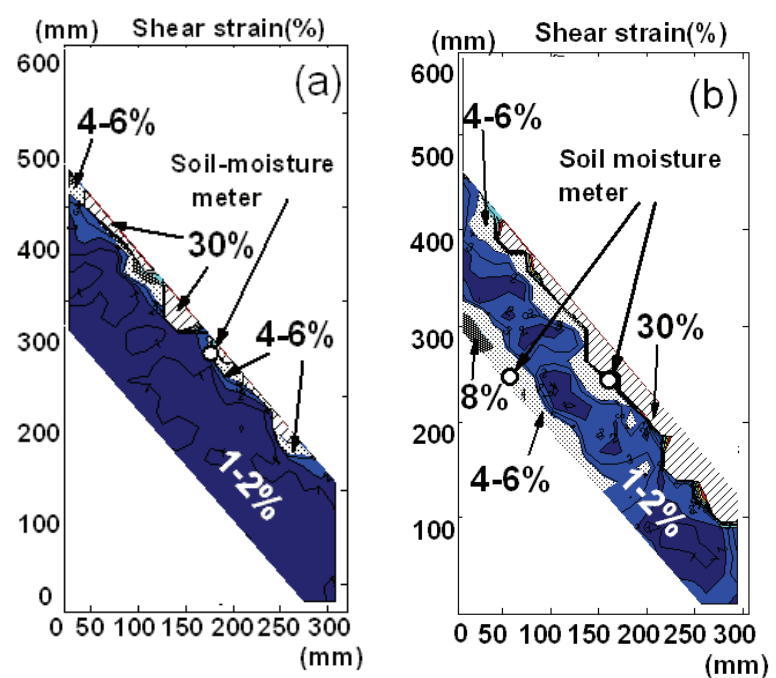

図-19 摩擦係数の違いによるせん断ひずみの変化 ;

(a) $\mu=2.81$, (b) $\mu=0.33$

のである，写真に示すように，両ケースともに同位 置にすべり線が発生している。飽和度挙動では（図 -20 参照）, 層厚 $t=75 \mathrm{~mm}$ のケースでは降雨開始後 飽和度が急増している。一方，層厚が $t=100 \mathrm{~mm} の$ ケースでは降雨開始後徐々に飽和度が増加し，斜面 内に雨水が浸透していく過程が確認できる. 両ケー スのように，層厚が薄い場合では，降雨の斜面内一 の浸透が速く，飽和度が急激に上昇することによっ て早期に崩壊に至ったと考えられる。矢田部ら 22) によれば，層厚が増加するほど崩壊が発生するまで に必要な総雨量が増加する傾向にあると報告されて いる。.また透水係数が大きく，層厚が薄い斜面ほど 短時間の豪雨に対して崩壊が生じ易い傾向があると 指摘 ${ }^{23)}$ されていることからも，本試験結果はそれ を良く説明したものであろう。崩壊に至らなかった 層厚 $t=125 \mathrm{~mm}$ 以上のケース（ここでは $200 \mathrm{~mm}$ の ケースを提示（図-21 参照））では斜面内の飽和度 は早期に定常状態に至っている 24),25)。これは，斜 面内で降雨による水の流入と流出が平衡状態に達し, 土塊自重がこれ以上増加しないことを意味している。 

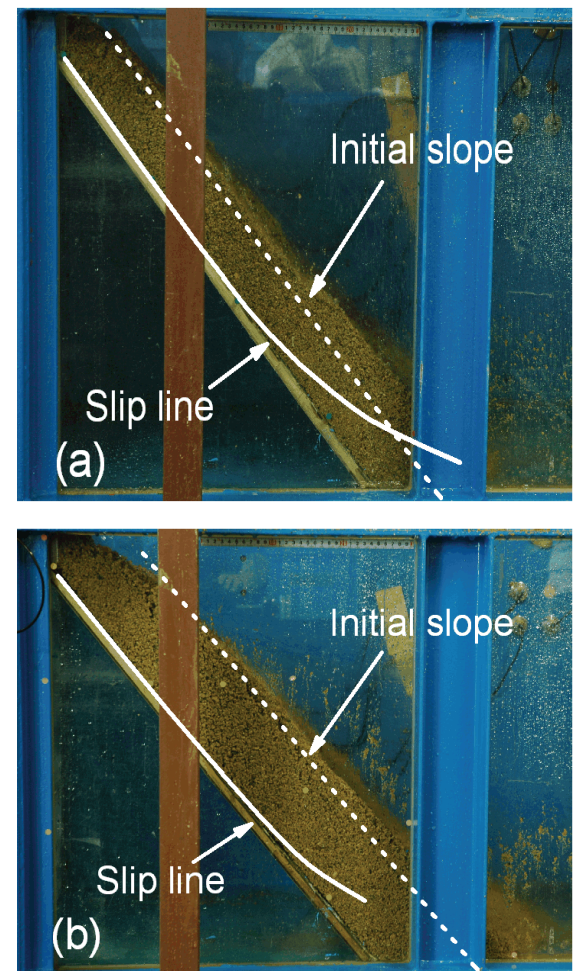

写真-5 崩壊後の斜面形状の様子 ;

(a)層厚 $t=75 \mathrm{~mm}, \quad(\mathrm{~b})$ 層厚 $t=100 \mathrm{~mm}$

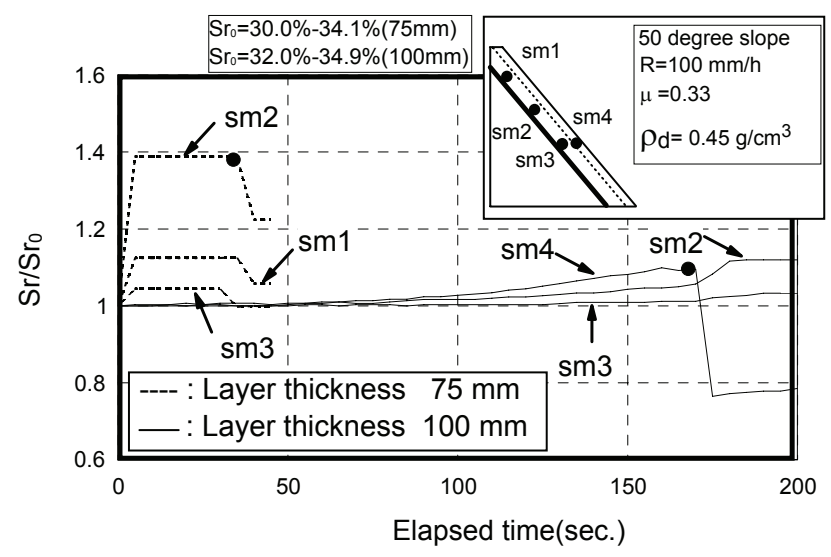

図-20 層厚の違いによる飽和度の変化

結果的に, 層厚が増加する（土被り圧が増加する） ことによって初期のせん断抵抗が大きくなり，降雨 による自重増加の影響がそれと比べてそれほど大き くならなかったことが崩壊に至らなかった理由と言 える.

（2）斜面表層崩壊を引起す各影響因子の力学的相 互関係

上述の結果から, 特に斜面崩壊は不透水層境界部 の摩擦や斜面角の違いに影響されていることがわか った。ここでは得られたすべてのデータ 18) 211,241,25) にもとづいて, その崩壊を引起寸影響因子の関係を 以下のように整理する.

図-22(a)，(b) と（c) は本研究で得られた斜面角と

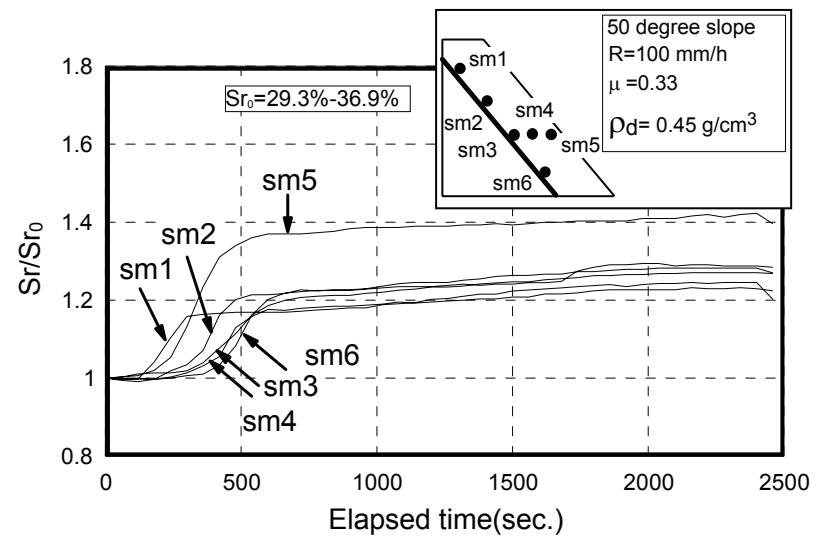

図-21 層厚 $t=200 \mathrm{~mm}$ の飽和度挙動
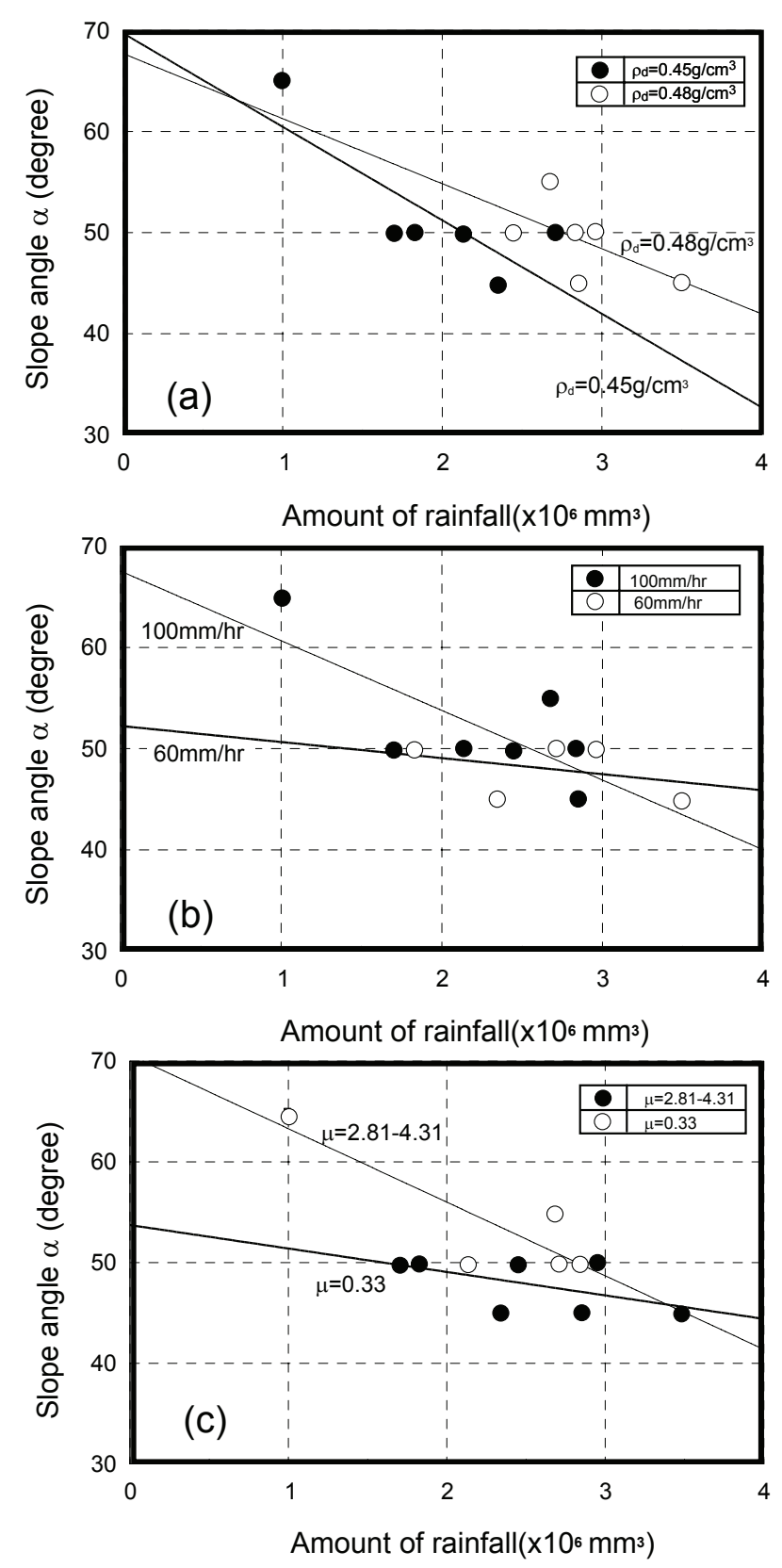

図-22 斜面角と崩壊までの総雨量との関係;

(a)密度, (b)降雨強度, (c)摩擦係数 


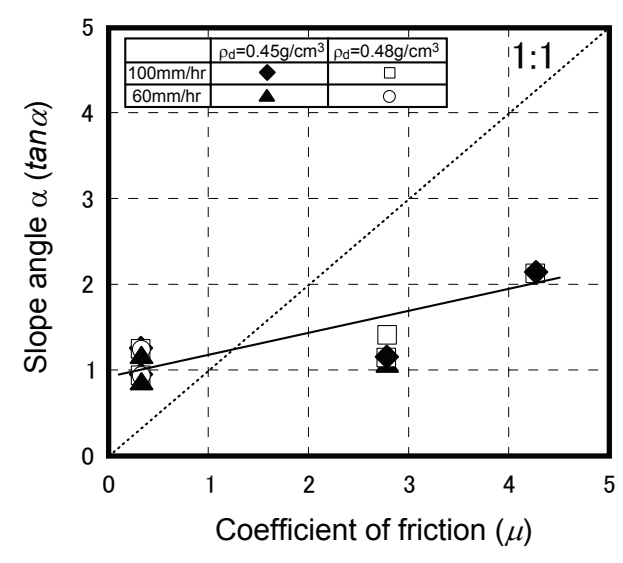

図-23 崩壊時の斜面角と摩擦係数の関係
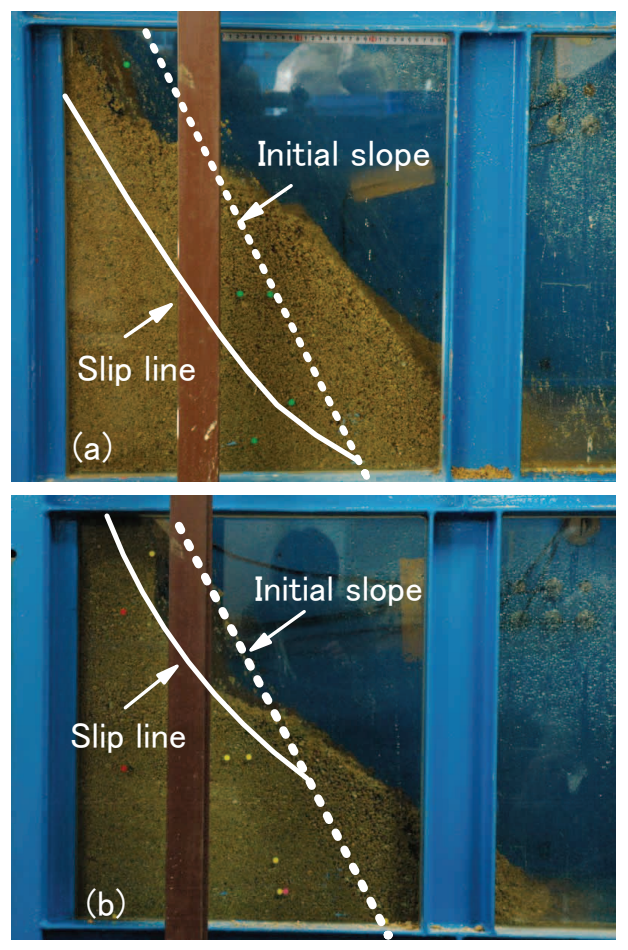

写真-6 崩壊後の斜面形状 ; (a) $w_{0}=70 \%$, (b) $w_{0}=40 \%$

崩壊までの総雨量との関係を示したものである、ば らつきはあるものの, 斜面角が高くなるにつれて総 雨量が減少する傾向が各パラメータとの関係におい て認められる. 回帰直線の勾配に着目寸ると, 降雨 強度と摩擦係数の影響が大きいようである。特に, $65^{\circ}$ 斜面では降雨強度, 摩擦係数の影響が明確に現 れ, 力学的安定を議論する上では重要な極值ポイン 卜になっている ${ }^{18), 21)}$. このような斜面角と総雨量 の関係は実フィールドにおいても指摘されており, 本試験結果は, 一般的に言われている降雨時の崩壊 現象を定性的に表現しているものと言える.

崩壊時の斜面角之不透水層境界部の摩擦係数の関 係を図-23に示寸. 図は, 物理的意味が同等な条件 になるように, 斜面角 $(\tan \alpha)$ と不透水層境界部の
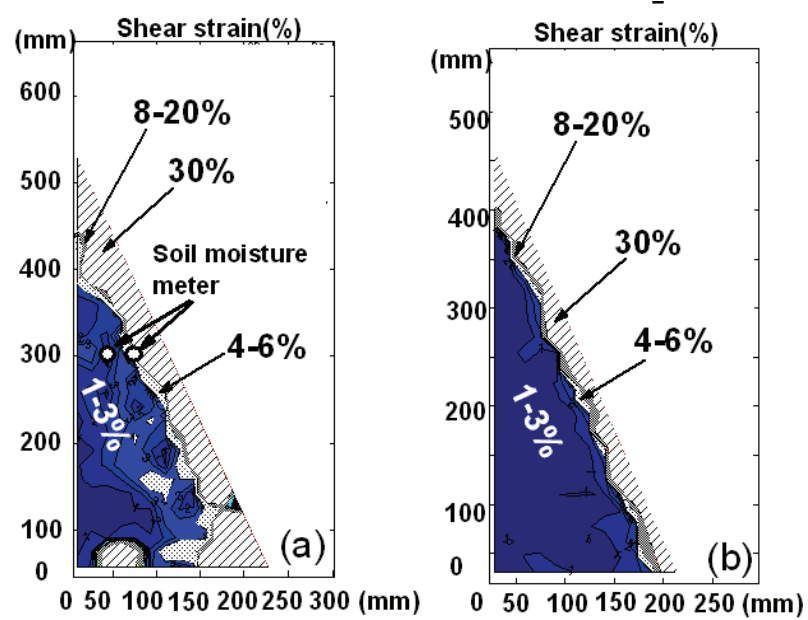

図-24 初期含水比の違いによるせん断ひずみ の変化 ; (a) $w_{0}=70 \%$, (b) $w_{0}=40 \%$

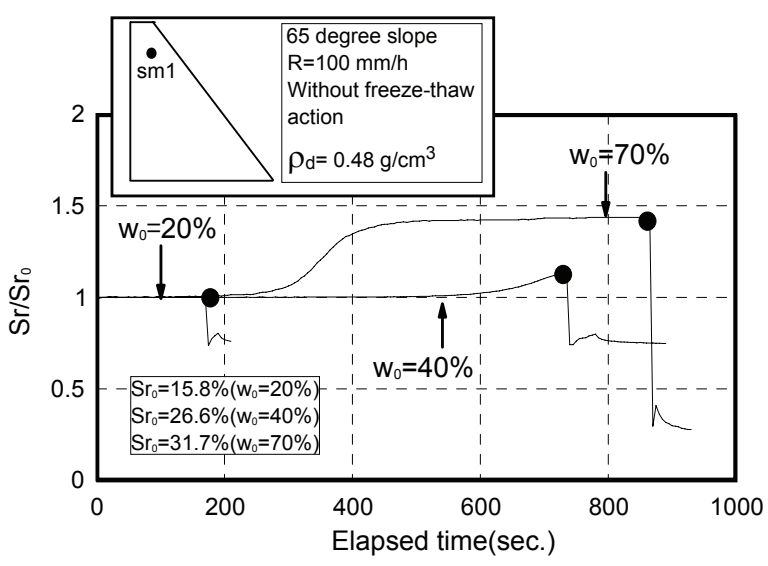

図-25初期含水比の違いによる飽和度の 変化 $(\mathrm{sm} 1)$

摩擦係数 $\mu$ により整理している. 図中には $1: 1$ の 対応線も併記している. 図からわかるように, 降雨 強度・密度の違いにかかわらず，崩壊時の斜面角之 摩擦度の間には右上がりの一義的な関係が存在して いる. 摩擦係数 $\mu$ がおおよそ 1.2 以下では崩壊に対 する摩擦係数の影響が大きく, 1.2 以上では摩擦係 数よりも斜面角の方が斜面崩壊に寄与していること がわかる，それゆえ，斜面角の大きさを把握するこ とは不透水層の摩擦の崩壊に対する相互関係を明ら かにすることができることを示しており，このこと はさらに力学的に, 合理的な崩壊の評価をすること が可能であることを示唆している.

\section{（3）斜面内不飽和力学挙動からみた表層崩壊機構}

力学的視点から各パラメータの斜面崩壊に対する 寄与が相対的に示された。ここでは, 斜面崩壊に及 ぼす素因，すなわち火山灰質土斜面内の保水能力と 崩壞機構との関係を定量的に議論している.

写真-6, 図-24 と図-25 は, 初期含水比を変化さ 
せた同一形状の斜面における変形挙動と飽和度挙動 ついて示したものである（Case10）。変形挙動では, 初期含水比 $w_{0}$ が変化することによって, 発生する すべり線の位置に変化が表れている。一方, 飽和度 はその収束值に変化が認められるものの, 前述と同 様，その寸心゙り線発生位置付近（sm1）では崩壊時 を境に増加一減少傾向を示寸。これより，初期含水 比の相違は斜面内の飽和度の発達の仕方やすべり線 の発生位置に影響を及ぼしていることがわかる。一 方，同地点の間隙水圧（pw1） は増加傾向にあるも のの，不透水層がある場合と同様，かなり小さく， 斜面崩壊は自重効果によるところが大きい（図-26 参照).

このことを明らかにするために，斜面安定解析に より算出したすべり線の半径 $r$ と初期含水比 $w_{0}$ の 関係を整理してみた（図-27 参照）. 安全率はFs= 1 とし, 図中に示す各パラメータは要素試験 ${ }^{15)} ら$ びに模型実験で発生した崩壊時の間隙水圧值の最大 值（ $u=0.5 \mathrm{kPa})$ を用いて算出されている. なお，こ こではすべり線の形状は円弧で, 間隙水圧は一様分 布とし, 含水比の増加にともなう自重増加は斜面全 体に均一に起こるものとして簡易的に解析している ことから，参考值とみなされるべきである. 図中に は実測されたすべり線から推定した值も併記してい る. 実験結果と解析值に相違はあるものの, 初期含 水比が減少するにしたがって，すべり半径は小さく なっている。この事実は，初期含水比が低いほど， 降雨の浸透水量により自重が増加し, 表面付近から 急速に不安定になって崩壊に至ったことを示すもの であろう。このことは飽和度の変化からも同様に伺 える（図-25参照）。

これらの結果にもとづいて，試験開始からピーク または定常になるまでの斜面内保水量 $V_{w}$ と初期含 水比 $w_{0}$ との関係を示してみた（図-28 参照）. 図 中には, 後述する凍結融解履歴有の場合もプロット している. なお, 点線は初期含水比の増加に伴う保 水量の増加を示す。図より, $w_{0}=40 \%$ 以上になれば, 崩壊に至る保水量の増加量はほぼ一定になっている. また，全保水量と初期含水比の間にユニークな関係 が存在している.このように，初期含水比 $w_{0}$ によ って崩壊保水量が一義的に決定されていることは興 味深い.

以上のことを総合すると，本試験の範囲では，斜 面表層崩壊は不透水層からの水位上昇ではなく, 飽 和度の発達の仕方（保水量の変化）に強く影響され ていることが明白であると言えよう。また，初期含 水比の違いによってすべり線の発生位置に影響を及 ぼすことが定量的に示された. 特に, この保水能力

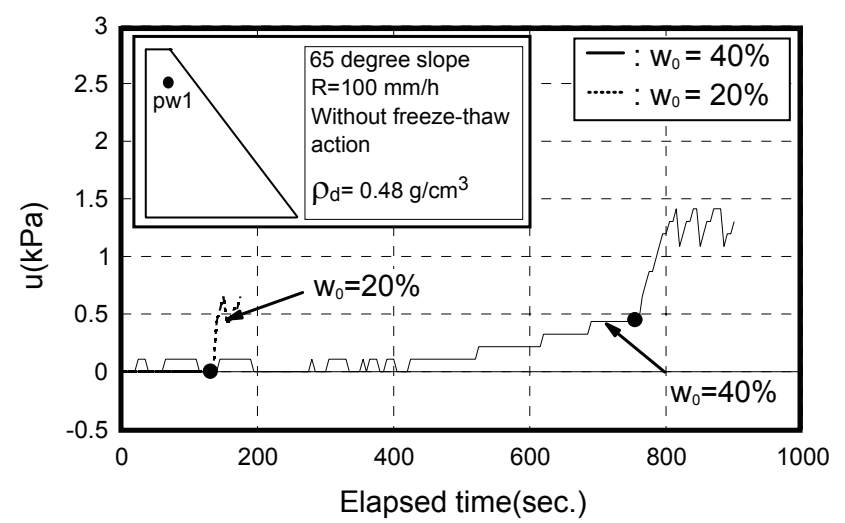

図-26 初期含水比の違いによる間隙水厓変化（pw1）

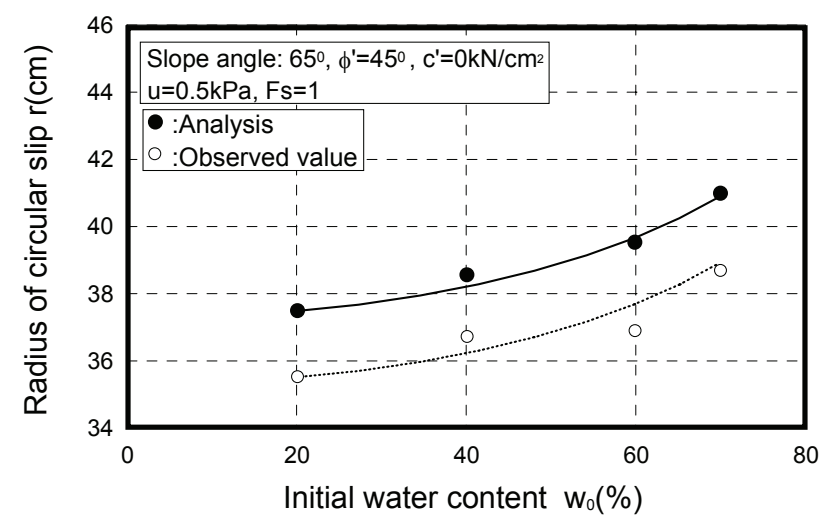

図-27 初期含水比の違いによるすべり半径の変化

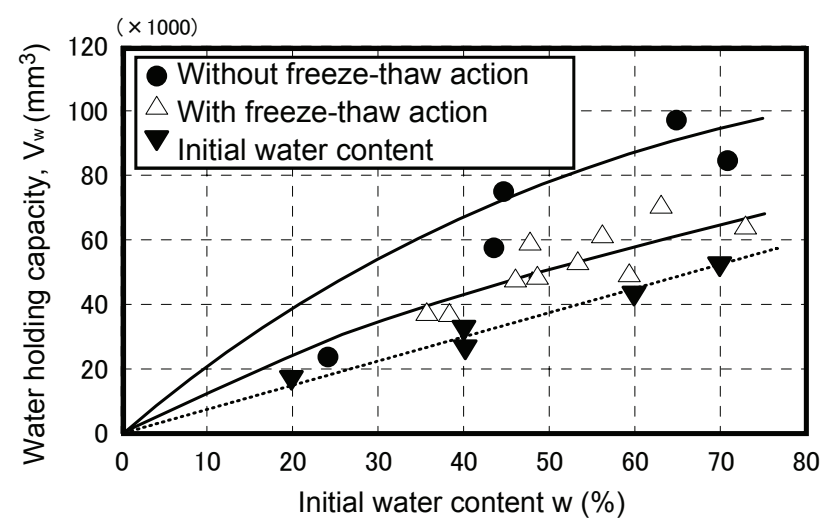

図-28初期含水比の違いによる崩壊時保水量の 変化

は初期含水比に依存し，飽和度の上昇にともなって その増加割合は一定になっている. Ishikawa ら ${ }^{26)}$ は 柏原火山灰土試料の不飽和力学挙動を要素試験より 調べ, その結果, 飽和度が $60 \%$ 以上（初期含水比 40\%以上）になればサクションが消失することを示 している。この事実は，初期含水比が低い場合では， 不飽和透水係数が小さくなるため斜面内に保持され る水量は小さくなることを示唆するものであり，前 述の本模型実験を良く表現したものであろう。いず れにしても,このことからサクションの変化や飽和 

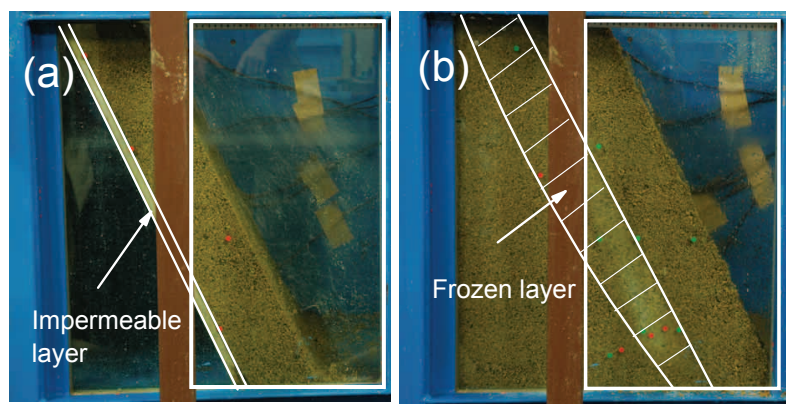

写真-7 試験前の斜面の状況 ; (a)不透水層, (b)凍結層
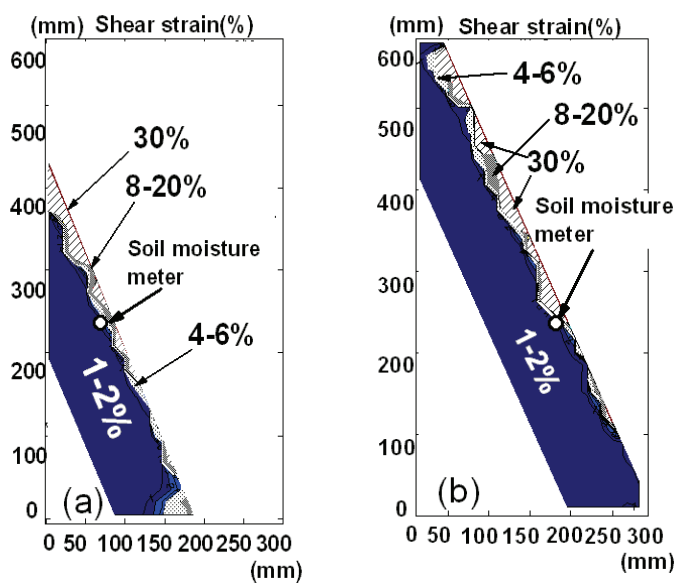

図-29 飽和度ピーク時のせん断ひずみ分布；

(a)不透水層(Case4), (b)凍結層(Case8)

度の変化を把握することは斜面表層崩壊予知ならび に崩壞機構を把握する上で重要であることが明らか にされたと言える.

\section{（4）凍結層の存在が斜面表層崩壊に及ぼす影響}

次に，斜面内に凍結層を設けた場合について，同 様の降雨試験を行った（Case6〜Case8）。この試験 では, 8 時間凍結させた斜面の上に層厚 $t=50 \mathrm{~mm}$ ま たは $100 \mathrm{~mm}$ の試料を 30 分以内に堆積させて降雨 試験を行っている. 前述のように, 斜面を凍結させ た際の斜面内の温度変化およびその状況を写真-1 と図-3に示寸.

写真-7 と図-29 は, 凍結斜面の摩擦係数と基本的 に同じ摩擦係数 $(\mu=4.31)$ として考えられる不透 水層のケース (Case4) と, 凍結面上に試料を堆積 させた Case8 の斜面形状及び飽和度ピーク時の斜面 内のせん断ひずみ分布を示したものである、試験条 件は斜面角 $\alpha=65^{\circ}$, 降雨強度 $R=100 \mathrm{~mm} / \mathrm{h}$, 斜面密 度 $\rho_{d}=0.45 \mathrm{~g} / \mathrm{cm}^{3}$ である. なお, PIV 解析は写真の四 角形で囲まれた範囲（白線内）が対象である。図か らわかるように, 両ケースにおいても飽和度ピーク 時における斜面内のせん断ひずみ分布に顕著な差異 は認められない。図示は省略したが, 崩壊後の両者

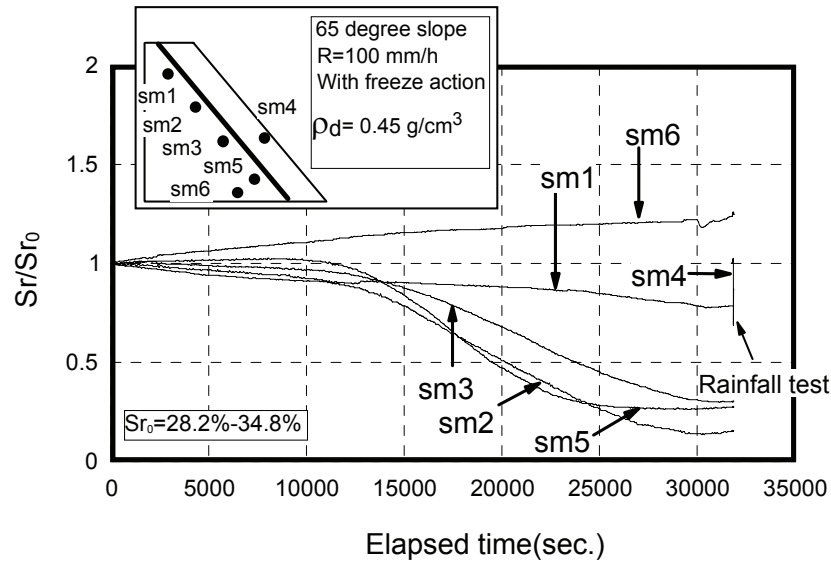

図-30 凍結時の飽和度の変化

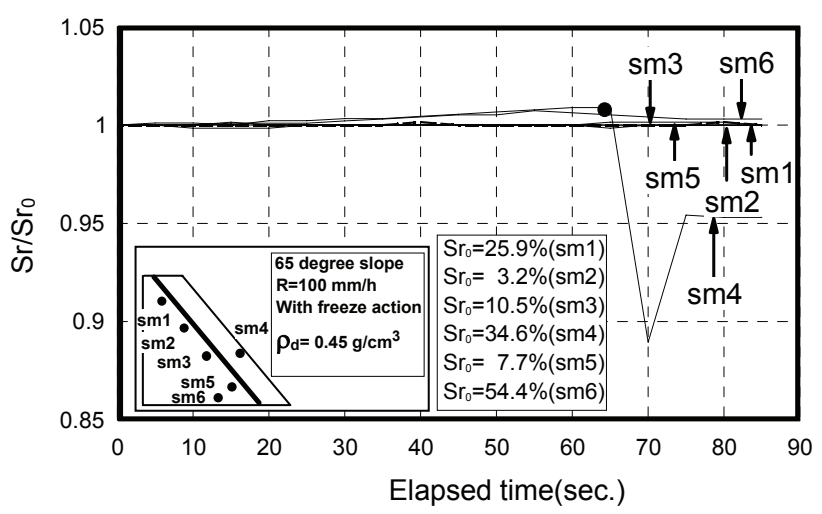

図-31 降雨実験中の飽和度挙動

の斜面形状（すべり土塊の堆積角）も同様の変形パ ターンであった。 これらのことから, 凍結層を不透 水層と寸る場合と摩擦係数 $\mu=4.31$ の不透水層を設 置した場合とでは変形挙動に違いがないようである.

一方, 飽和度挙動について着目すると（図-30 参 照），凍結過程では凍結の影響がある表層付近 （sm1〜 sm5）の飽和度は徐々に減少している。 な お，この減少は，凍結による水分の移動ならびに間 隙の自由水が凍結することによる誘電率の低下 ${ }^{27)}$ の両者が影響しているが, 主たる要因は水分移動に よることが予備実験において確認されている.一方, 降雨開始から崩壊までの挙動では, 前述の不透水層 と同様, すべり線発生位置付近の飽和度 ( $\mathrm{sm} 4)$ は 徐々に上昇し, ピークに到達した後, 急激に減少し ていることが確認される（図-31参照）。

それゆえ，このことは，春季に起こりうる斜面表 層崩壊では凍結層が不透水層として働くことが崩壊 誘因の 1 つになる可能性があることを示したもので あろう。

\section{（5）斜面表層崩壊に及ぼす凍結融解履歴の影響}

北海道のような積雪寒冷地では, 冬季間に地盤が 凍結し, 春季の気温上昇によって融解するといった 


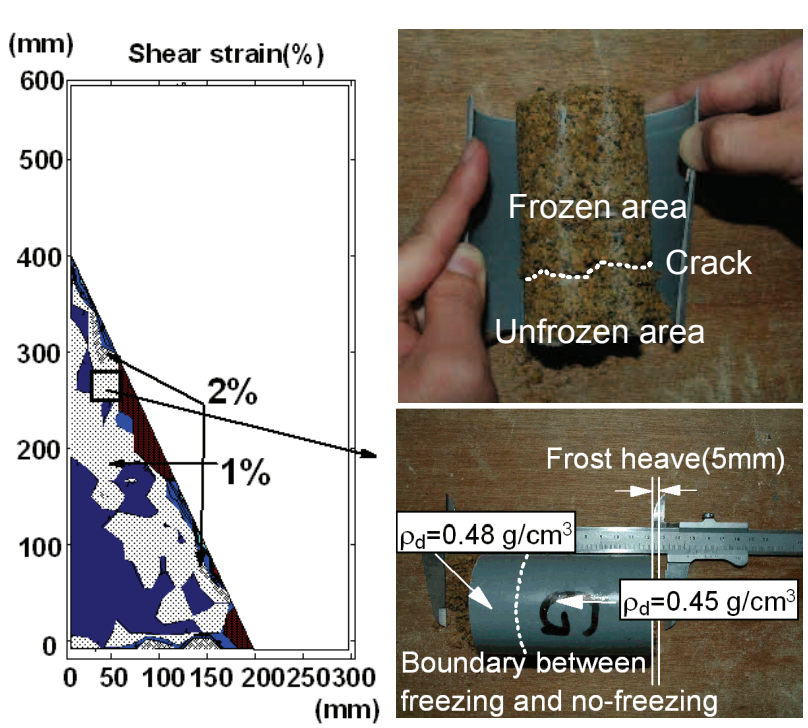

図-32 凍結後のせん断ひずみ分布と斜面内に設置 した密度変化用モールドの状況

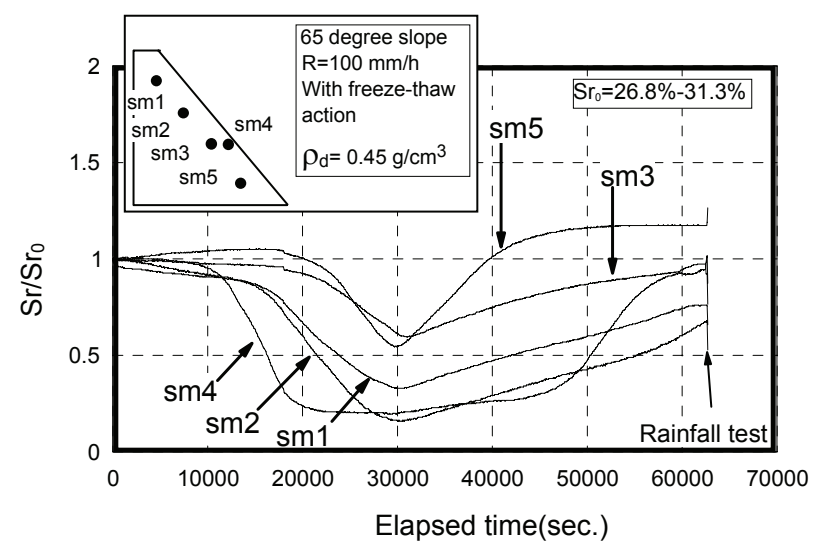

図-33 凍結融解時の飽和度の変化

現象が繰返されている，ここでは，凍結融解履歴を 与えた模型斜面の崩壊モードの変化を明らかにした (Case9) .

前述の図-4 と図-5 に, 凍結融解過程における斜 面内の温度変化とその温度分布をそれぞれ示す. 斜 面は $\alpha=65^{\circ}$ ，ドライアイスで 8 時間凍結させた後， 室温 $30^{\circ} \mathrm{C}$, 湿度 $60 \%$ の下，9 時間で融解させたも のである.図より, Case6〜Case8 と同様, 凍結開 始から 8 時間（28,800 秒）後に斜面表層から $50 \mathrm{~mm}$ の深さまで凍結していることがわかる. また融解開 始から 7 時間（凍結融解過程で 54,000 秒）後に温 度センサーの值は， $0^{\circ} \mathrm{C}$ 以上になっている。予備実 験では温度計の值が $0^{\circ} \mathrm{C}$ 以上ななっも，センサー 周辺には凍結層が存在していたことから, 凍結層が 完全に融解するその 2 時間後, すなわち融解から 9 時間以降に降雨試験を行った。

図-32 に，凍結履歴直後の斜面内せん断ひずみ分 布を示す。図より，凍結履歴を受けたエリアでは，

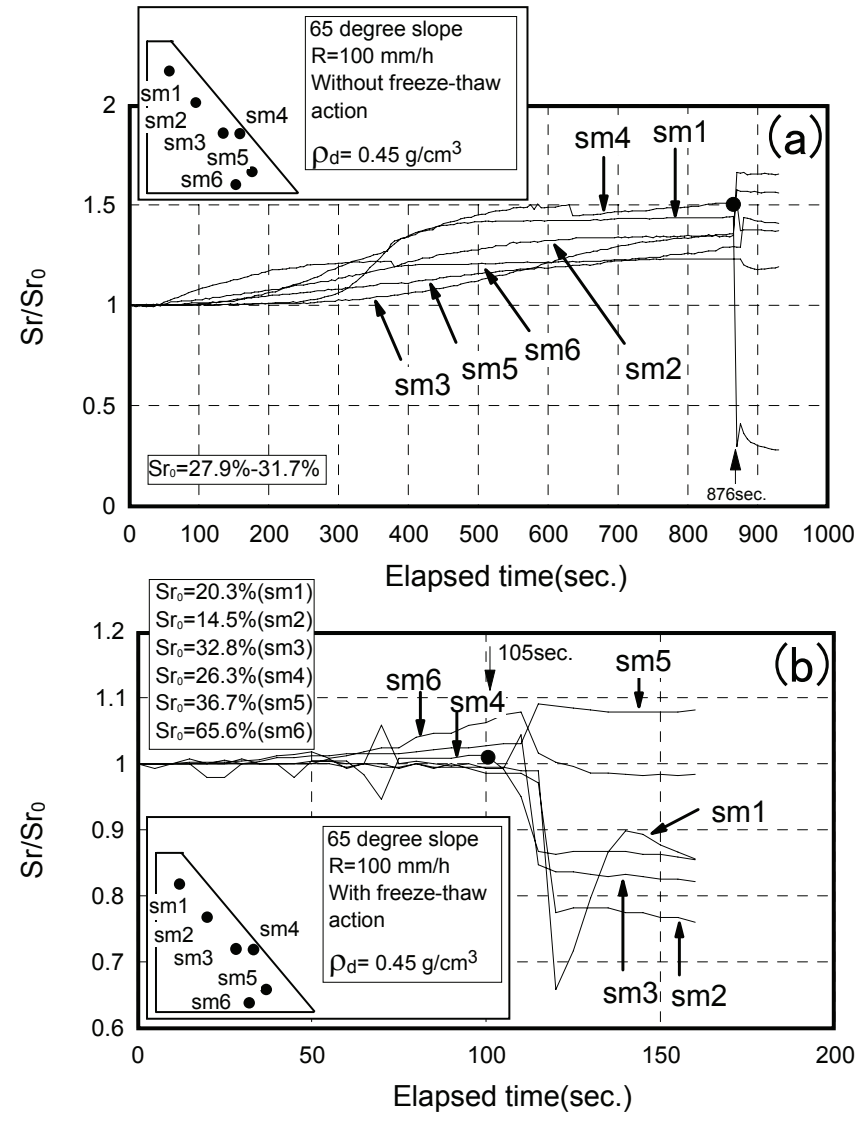

図-34凍結融解履歴有無による降雨時の飽和度変 化 ; (a)履歴無， (b)履歴有

せん断ひずみが 1〜2\%発生していることがわかる. また，斜面内に設置した密度変化計測用のモールド では凍結過程によって斜面内に構造変化（クラック の発生および密度変化）が現れていた（写真参照）。 実際，斜面天端部においても凍結層の境界において 目視できるクラックを確認している.

図-33に凍結融解過程における飽和度挙動を示す. 凍結過程において, 凍結層付近の飽和度は減少して いる（sm1， sm2， sm3， sm4， sm5）。また, 融解 過程においては凍結部で保持されていた水分が融解 によって周囲に移動 ${ }^{28)}$ するため, 凍結層の飽和度 は再び上昇している。他の試験（Case9）において も同様の結果が得られている.

次に, 降雨時の凍結融解履歴の有無による飽和度 の変化を示す（図-34 参照）。履歴を与えた場合で は，105 秒で崩壊に至り（(b)図参照）, 凍結融解 履歴を与えない場合では 876 秒で崩壊に至った

（（a）図参照）。この時の斜面内の代表的な飽和度 （sm4）の值は, 履歴有の場合では $S r=26.6 \%$, 履 歴無の場合では $S r=42.2 \%$ 収束していた。この収 束值の違いは, 前述の凍結融解履歴を受けた斜面の 構造変化（クラックの発生および密度変化）が生じ たことに起因しているようである. 

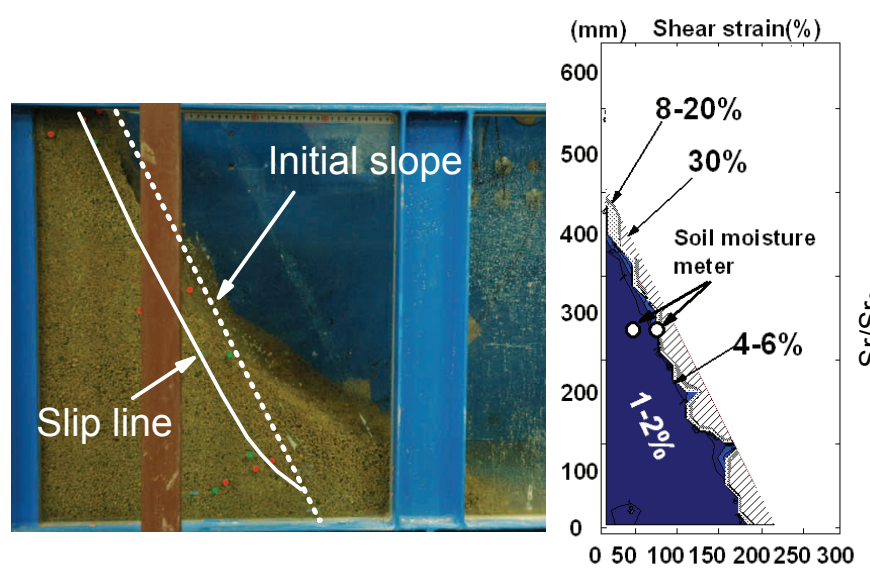

写真-8 (左) と図-35(右) 崩壊後の形状とせん断ひずみ分布

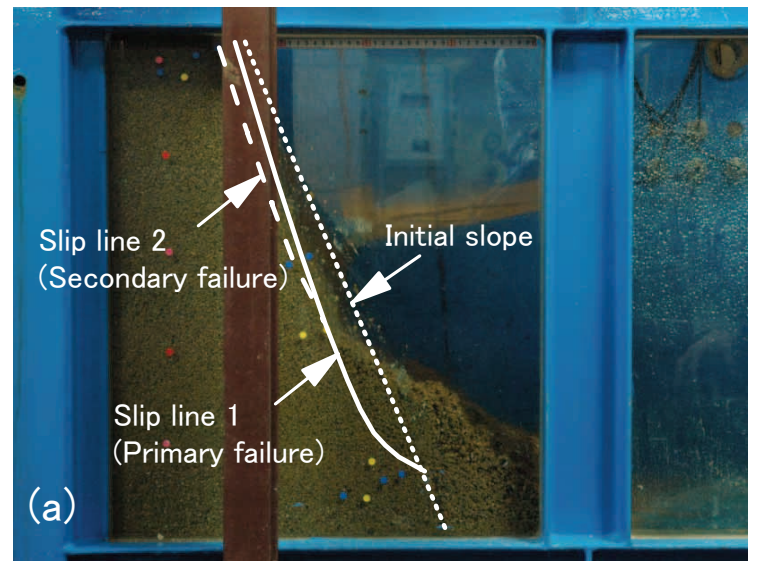

写真-9 降雨後の斜面変形の様子; (a)融解 9 時間, (b)融解 40 時間

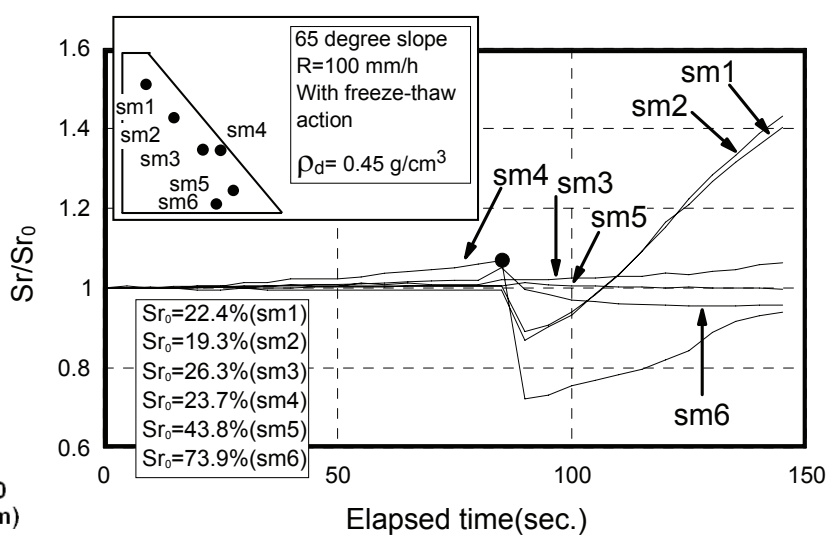

図-36 融解 40 時間の降雨時飽和度挙動

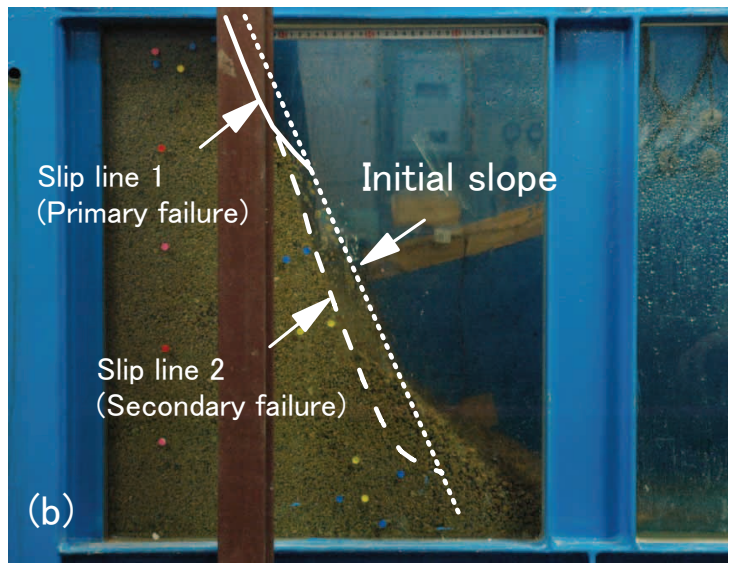

写真-8 と図-35に，凍結融解履歴有の崩壊後の斜 面形状および飽和度ピーク時の斜面内のせん断ひず みを示す。同条件下の写真-6 (a) ならびに図-24 (a) との比較より，履歴を与えることによってすべり線 の発生位置が浅くなり，変形モードに違いが認めら れる。すなわち，す心゙り線は履歴を与えた場合では 表層に近く, 履歴無しの場合ではより深い位置に発 生する傾向にある.

さらに，融解時の温度勾配の違いによる力学特性 の変化について調べてみた。 ここでは, 初期含水比 $w_{0}=55 \%$ と $70 \%$ の斜面において，9時間かけて融解 させた後に降雨試験を行ったケースと, 室温を $10^{\circ} \mathrm{C}$ に保ち 40 時間かけて融解させた後に降雨試験 を行ったケースを比較する。

図-36に，初期含水比 $w_{0}=70 \%$ における 40 時間 融解時の降雨時の飽和度の変化を示寸. 降雨開始後, 飽和度は徐々に上昇し, 表層部の飽和度（sm4）が ピークに達した後, 崩壊の進行に伴い減少している. これは, 図-34 (b) の9 時間かけて融解させたケース と同様の挙動を示している。また，崩壊に至った時 点の飽和度は $S r=25.3 \%$ であり，融解時間 9 時間の
崩壊時の飽和度 $S r=26.6 \%$ と同程度であった。崩壊 後のす心゙り線発生位置においても相違は認められて いない、19).

一方，初期含水比 $w_{0}=55 \%$ では，写真 -9 に示す ように，融解時間の違いによって崩壊エリアとその 発生時期に違いが現れた。ここでは 1 次崩壊（実 線）と 2 次崩壊 (点線) と称することにする. 写真 より融解時間が早くなるにつれ，1 次崩壊の領域が 大きくなっていることがわかる．しかしながら，融 解時間の違いに関わらず，2 次崩壊に至ったすべり 線は最終すべり線と同じ位置に発生していた。この ことから，初期含水比の違いによって自重効果の影 響の度合いは変化するものの, 基本的に融解時の温 度勾配の違い（融解速度の違い）が力学特性に与え る影響は小さいようである。

次に, 凍結融解履歴の回数の影響を示す. 積雪寒 冷地では凍結融解履歴を経年受けていることから， 自然斜面や法面の安定性に及ぼす凍結融解履歴回数 の影響を定量的に評価する必要がある。ここでは, 凍結融解履歴回数の違いが変形特性に及ぼす影響を 検討した. 山木ら ${ }^{29)}$ は，2007 年 12 月 8 日 2008 年 


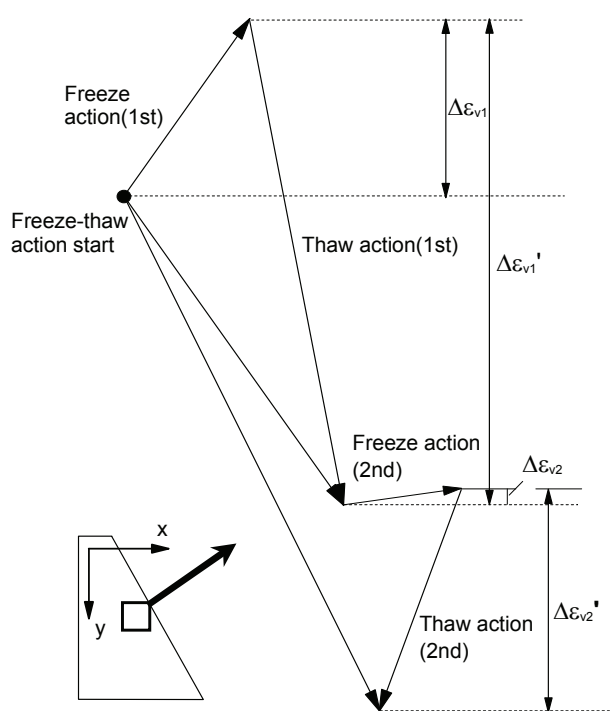

図-37 凍結融解履歴 2 回時のひずみベクトル の変化

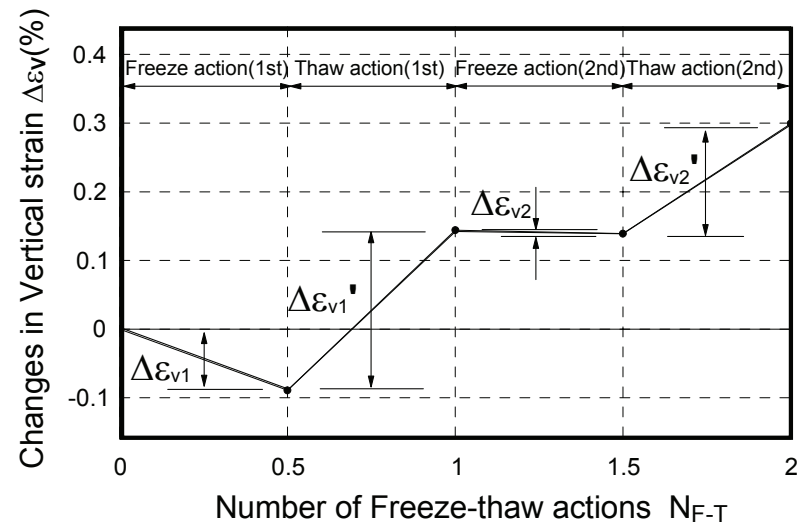

図-38 凍結融解の履歴回数と鉛直ひずみ増分 の関係

4 月 1 日の札幌市内の観測データにおいて冬期間の 凍結融解履歴回数は 6 回であること，また一連の要 素試験から凍結融解履歴回数の増加にともなう初期 せん断剛性の変化は履歴 1～2 回程度で収束するこ とを示している。この事実にもとづいて，ここでは 履歴回数を 2 回とした.

図-37 は, PIV 解析より算出した斜面内任意要素 の変位ベクトル連結図である。眓中の $\Delta \varepsilon_{v i}$ と $\Delta \varepsilon_{v i}^{\prime}$ は， それぞれ凍結開始から凍結後と凍結後から融解後の 鉛直ひずみの増分を示し， $i$ は履歴回数を意味する. 前述のとおり, 履歴 1 回目では, 変位は凍結過程に おいて斜面表面に対して垂直方向に進み，融解過程 において重力方向（y 方向）へ進行している. 履歴 2 回目の変位方向は履歴 1 回目の影響による斜面内 構造の変化によって 1 回目よりもさらに重力方向へ 進行し，そのひずみ量は小さくなっている。この現 象は，従来，指摘されている事実例えば 30) と同様であ
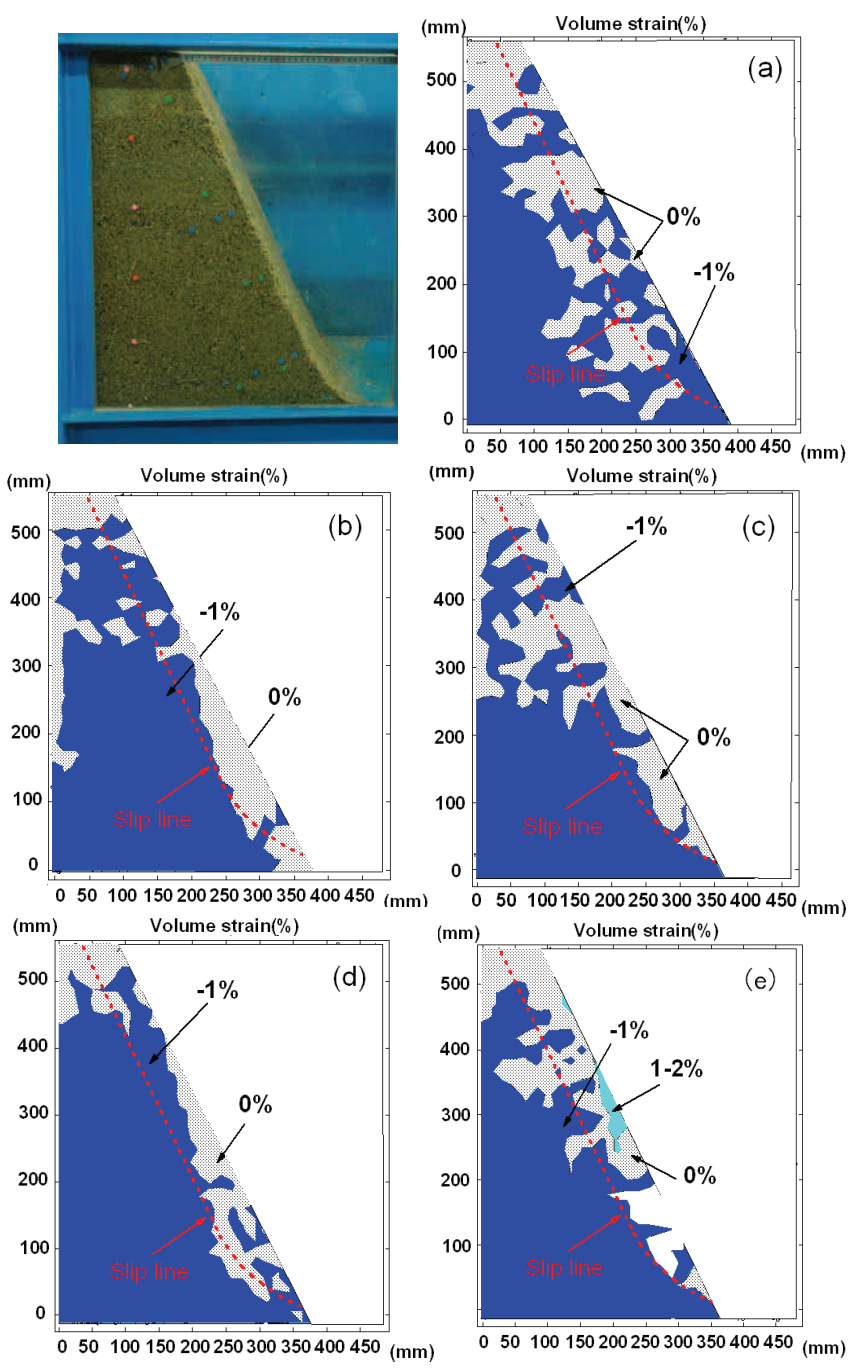

図-39 凍結融解中の体積ひずみの変化;

(a)凍結後 2 時間, (b)凍結終了後（1 回目）

(c)融解後（1 回目），(d)凍結後（2回目）

(e)融解後（2 回目），写真 : 凍結開始時点

る。なお，実測による凍結深さは，1 回目および 2 回目ともに約 $80 \mathrm{~mm}$ であり，相違は認められなかっ た.

図-38に鉛直ひずみの変化量の具体值を凍結融解 履歴回数 $N_{F-T}$ との関係で示す. 凍結過程の履歴の違 いで比較すると, 凍結履歴回数の増加に伴い鉛直ひ ずみは収束傾向にある。このことから，山木らの研 究結果 ${ }^{29)}$ と同様，凍結融解履歴は変形特性に影響を 及ぼし，その回数の影響は 1 回目が支配的であるこ とが示された。

図-39 は PIV 解析から求めた凍結融解時の体積ひ ずみの変化を示したものである。斜面表層部では凍 結初期に収縮傾向になり（（a）図参照），その後膨 張傾向に転じるようである（(b)図参照）。本試料 は凍上性の低い材料ではあるが，斜面内では，はじ めに凍縮 ${ }^{31)}$ が起こり, その後局所的に霜柱が成長 


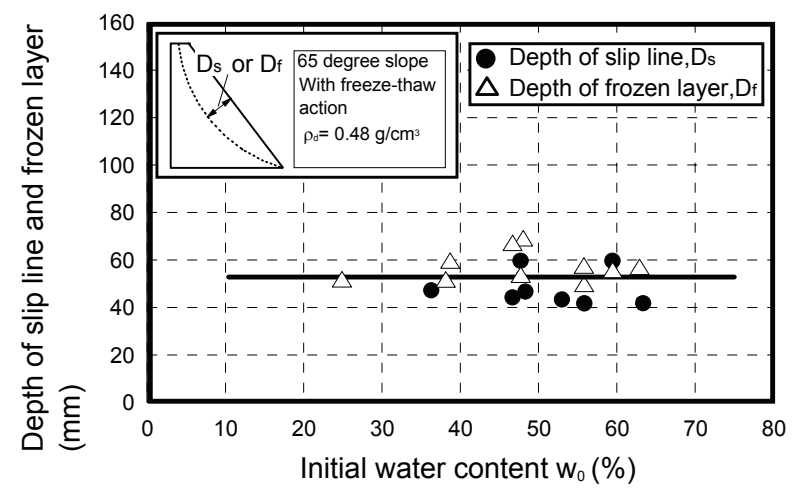

図-40 実測すべり線と凍結層の深さの関係 (Case9)

し，体積膨張に転じていると推測できる．このこと は, 図-32 中の写真の状況からも確認できる. 融解 終了後（(c) 図参照）および 2 回目の凍結融解終了 後（（d）と（e)図参照）では, その挙動はほぼ一定值 に落ち着いていており, 表層部の体積ひずみゼロ領 域の変化はほとんど見られない。 なお,この領域の 深さはすべり線の深さとほぼ一致していた.

以上のことから，凍上性の低い材料から構成され る斜面においても局所的に凍結・凍上現象は進む可 能性はあり，またその影響部（凍結融解部）は塑性 平衡状態になっていると指摘できる. さらに, 凍結 融解履歴によって生じる体積変化特性（ダイレイタ ンシー特性）を把握することによってその影響度を 一律に評価することが可能であると言えそうである。 この凍結融解履歴によるダイレイタンシー挙動は, 図-28 に示す保水量の変化からも明らかであり, 凍 結融解履歴を与えることによって骨格構造に変化が 生じていることを示唆するものであろう。

図-40 は, Case9 における崩壊深さ（すべり線の 深さ）と凍結深さの比較を示したものである. 図よ り, 初期含水比の違いによらず, 両者に明確な相違 は認められない。このことは, 凍結深さからすべり 線の発生位置を簡易に推定できることを示しており， 興味深い事実である.

以上のことを総合すると, 凍結深さからすべり線 の発生位置（崩壊深さ）を推定し, さらに土㙋水分 計等の計器を設置し, 崩壊に至らしめる保水量をモ ニターできれば，降水による斜面崩壊の危険度を予 測することが可能になると言える.

\section{4. 結論}

火山灰質土試料を用いた一連の降雨模型実験より， 限定された条件ではあるが，次のような結果を得た。 (1) 火山灰質土斜面の表層崩壊は不透水層の斜面角,
底部摩擦，降雨強度に影響されるが，斜面密度の影 響は小さい.

(2)斜面内の初期含水比の違いは, 降雨による浸透 特性ならびに斜面内の保水性に影響を及ぼし，す心゙ り線の発生位置ならびに斜面表層崩壊領域の変化を もたらす。

(3)凍結・融解のような温度変化を受けた斜面は, その過程において, 凍結層と非凍結層との境界の構 造の変化によって崩壊が誘発される.

(4)凍結融解履歴を受けた斜面では, 表層崩壊に及 ぼす融解時の温度勾配の影響は基本的に小さい。

(5)凍結融解履歴の影響部は, 塑性平衡状態に導かれ るようであり, その評価は凍結・融解によるダイレ イタンシー特性の変化を適切に把握することにより 可能である.

謝辞：本研究を進めるにあたり，実験及びデータ整 理に室蘭工業大学卒業生 井野寿人, 島津大輔, 中 野博貴, 奥田健太各君の協力を得た。 また本研究に は科学研究費 基盤研究A（No.19201035: 代表 三浦 清一）と基盤研究B（No.16310121:代表 三浦清 一）の補助が与えられた。末筆ながら記して感謝の 意を表する。

\section{参考文献}

1) 鈴木輝之, 根岸正充 : 北海道の道路工事における凍 害 - 特に斜面, トンネル, 側溝について, 土と基礎, Vol.37, No.9, pp.65-70, 1989.

2) Miura, S., Yagi, K. and Asonuma, T. : Deformationstrength evaluation of crushable volcanic soils by laboratory and in-situ testing, Soils and Foundations, Vol.43, No.4, pp.47-57, 2003.

3）火山灰地盤の工学的性質の評価法に関するシンポジ ウム論文集, 火山灰地盤の工学的性質の評価法に関 する研究委員会, 地盤工学会北海道支部, pp.72-74, 2002.

4) 長谷川和義 他 21 名：平成15年台風 10 号北海道豪雨災 害調査団報告書, 土木学会水工学委員会, pp.1-181, 2004.

5）実務者のための火山灰土, 北海道火山灰土の性質と 利用に関する研究委員会, 地盤工学会北海道支部, pp.65-75, 2004.

6) Orense, R., Farooq, K. and Towhata, I. : Deformation behavior of sandy slopes during rainwater infiltration, Soils and Foundations, Vol.44, No.2, pp.15-30, 2004.

7) 豪雨時における斜面崩壊のメカニズムおよび危険度 予測, 地盤工学会, pp.35-48, 2006. 
8) 八木則男, 矢田部龍一, 榎明潔 : 降雨時の斜面崩壊 に対する限界降雨量，土木学会論文集，No.418/III-13， pp. 65-73, 1990.

9) 北村良介, 酒匂一成, 加藤俊二, 水島俊基, 今西 肇：降雨時のしらす斜面の浸透・崩壊に関する室内 土槽試験, 地盤工学ジャーナル, Vol.2, No.3, pp.149-168, 2007.

10) Olivares, L., Damiano, E., Greco, R., Zeni, L., Picarelli, L., Minardo, A., Guida, A. and Bernini, R. : An instrumented flume to investigate the mechanics of rainfall-induced landslides in unsaturated granular soils, Geotechnical Testing Journal, ASTM, Vol.32, No.2, pp.108-118, 2009.

11）北村良介：降雨時の斜面モニタリングと崩壊予測技 術の現状(小特集 降雨時の斜面モニタリングとリア ルタイム崩壊予測)，土と基礎，地盤工学会，Vol. 55, No.9, pp.1-3, 2007.

12）小島尚人, 大林成行, 北村良介：シラス自然斜面の 崩壊誘因推定支援を目的とした衛星熱赤外域情報の 活用方法の提案，土木学会論文集，No.749/VI-61, pp.99-110, 2003.

13）鳥居宣之, 沖村孝, 加藤正司 : 地震後の降雨による 斜面崩壊発生機構に関する実験的検討, 土木学会論 文集，No.1/C-61，pp.140-149， 2007.

14) Harris, C. and Davies, M. C. R. : Gelifluction : Observations from large-scale laboratory simulations, Arctic, Antarctic and Alpine Research, Vol.32, No.2, pp.202-207, 2000.

15）三浦清一, 八木一善, 川村志麻 : 北海道火山性粗粒 土の静的および動的力学挙動と粒子破砕, 土木学会 論文集，No.547/III-36，pp.159-170， 1996.

16) White, D. J., Take, W. A. and Bolton, M. D. : Soil deformation measurement using particle image velocimetry (PIV) and photogrammetry, Geotechnique, Vol.53, No.7, pp.619-631, 2003.

17) Ishikawa, T., Miura, S. and Ito, K. : Influence of freezethaw action on mechanical behavior of unsaturated crushable volcanic soil, Proc. of the $5^{\text {th }}$ International conference on Unsaturated Soils, 2010. (Accepted)

18）井野寿人, 川村志麻, 三浦清一, 石川達也 : 凍結 融解履歴を有する火山灰質土斜面の降雨時力学挙動 とその評価，地盤工学会北海道支部技術報告集，第 48 号, pp.97-106, 2008.

19) 川村志麻, 中野博貴, 三浦清一, 石川達也 : 凍結 融解履歴を有する不飽和火山灰質土斜面の降雨時力 学挙動, 地盤工学会北海道支部技術報告集, 第 49 号, pp.233-240, 2009 .

20) Kawamura, S., Kohata, Y. and Ino, H. : Rainfall-induced slope failure of volcanic coarse-grained soil in Hokkaido, Proc. of the $13^{\text {th }}$ Asian regional conference on Soil Mechanics and Geotechnical Engineering, ISSMGE, pp.931-934, 2007.

21) 川村志麻, 井野寿人, 木幡行宏 : 降雨による火山灰 質土斜面の崩壊機構とその影響因子，地盤工学会北 海道支部技術報告集，第 47 号，pp.171-180， 2007.

22）矢田部龍一, 八木則男, 榎明潔：降雨による砂質土 斜面の崩壊発生時期の予知法に対する検討, 土木学 会論文集，No.376/III-6，pp.297-305， 1986.

23）池田勇司, 榎明潔, 中村正邦：降雨による斜面表層 崩壊の理論モデルとその利用，第 53 回土木学会年次 学術講演会講演集, pp.452-453, 1998.

24）川村志麻, 井野寿人, 三浦清一, 石川達也 : 不透水層 を有する火山灰質土斜面の降雨時力学挙動, 第 63 回土 木学会年次学術講演会講演概要集, C 部門, pp.191-192, 2008.

25）井野寿人：凍結融解履歴を受けた火山灰質土斜面の 降雨時力学挙動に関する研究, 室蘭工業大学大学院, 平成 19 年度修士学位論文, 2008 .

26) Ishikawa, T., Miura, S. and Tokoro, T. : Effect evaluation of freeze-thaw action on hydro-mechanical behavior of unsaturated granular materials, Proc. of the $17^{\text {th }}$ International conference on Soil Mechanics and Geotechnical Engineering, ISSMGE, No.1, pp.833-836, 2009.

27) 山中勤, 開發一朗 : 寒冷乾燥地域における土壌水分 の TDR 測定 : 温度依存性と凍結・融解の影響, 電子 モノグラフ, No.1, 筑波大学陸域環境研究センター, pp.1-7, 2003.

28) 青山清道, 小川正二, 川澄修, 田村富雄, 福田誠 : 凍結一融解を与えた土の性質，土と基礎，Vol.25， No.7, pp.41-46, 1977.

29) 山木正彦, 三浦清一, 横浜勝司: 破砕性火山灰土の 変形特性に及ぼす凍結融解履歴の影響, 土木学会論 文集 C, Vol.65, No.1，pp.321-333， 2009.

30) 上野邦行, 苖大虎, 鈴木輝之, 山下聡 : 芝生保護法 面の凍結・融解過程における挙動観測(その 2)，第 43 回地盤工学研究会発表集, pp.989-990, 2007.

31）河野文弘：地盤の凍結と凍上, 土と基礎, 土質工学 会, Vol.27, No.7, pp.11-15, 1977 .

(2009.11.2 受付) 


\section{RAINFALL-INDUCED FAILURE OF UNSATURATED VOLCANIC SLOPE SUBJECTED TO FREEZE-THAW ACTION AND ITS MECHANISM}

\section{Shima KAWAMURA, Seiichi MIURA, Tatsuya ISHIKAWA and Shoji YOKOHAMA}

Collapse of slope formed from volcanic soils has been frequently caused in Hokkaido, Japan. This study aims at clarifying failure mechanism of volcanic slope caused by both rainfall and freeze-thaw action. In particular, the effects of freeze-thaw action, slope angle, density and friction of impermeable layer in the slope on mechanical behavior were detailedly investigated on volcanic slopes having several shapes. The results showed that; surface slope failure depends strongly on slope angle, the friction characteristics of impermeable layer and rainfall intensity, and the formation of frozen layer in spring season and the softening of slope by freeze-thaw action in summer season are important for evaluating the stability of volcanic slope. 